\title{
Perhubungan antara Konflik Kerja dan Keluarga terhadap Stres dalam kalangan Pekerja Kakitangan Awam
}

\section{(The Relationship between Work and Family Conflict with Stress among Civil Servants)}

\author{
Muhammad Daniel Aidil Mohd Narahim¹ (D), Mohammad Mujaheed Hassan²*iD, \\ Amna Md Noor ${ }^{3}$ (D) Azlina Mohd Khir ${ }^{4}$ (D), Wan Arnidawati Wan Abdullah5 ${ }^{5}$
}

\author{
${ }^{1}$ Jabatan Sains Kemasyarakatan dan Pembangunan, Fakulti Ekologi Manusia, Universiti Putra Malaysia \\ (UPM), Serdang, Selangor, Malaysia. \\ Email: muhddanielaidil@gmail.com \\ 2Jabatan Sains Kemasyarakatan dan Pembangunan, Fakulti Ekologi Manusia, Universiti Putra Malaysia \\ (UPM), Serdang, Selangor, Malaysia. \\ Email: mujaheed@upm.edu.my \\ ${ }^{3}$ Jabatan Sains Kemasyarakatan dan Pembangunan, Fakulti Ekologi Manusia, Universiti Putra Malaysia \\ (UPM), Serdang, Selangor, Malaysia. \\ Email: amna@upm.edu.my \\ ${ }^{4}$ Jabatan Sains Kemasyarakatan dan Pembangunan, Fakulti Ekologi Manusia, Universiti Putra Malaysia \\ (UPM), Serdang, Selangor, Malaysia. \\ Email: $\underline{\text { m azlina@upm.edu.my }}$ \\ 5Jabatan Pembangunan Manusia \& Pengajian Keluarga, Fakulti Ekologi Manusia, Universiti Putra \\ Malaysia (UPM), Serdang, Selangor, Malaysia. \\ Email: arnidawati@upm.edu.my
}

\section{CORRESPONDING \\ AUTHOR (*):}

Mohammad Mujaheed Hassan (mujaheed@upm.edu.my)

\section{KATA KUNCI:}

Konflik kerja

Konflik keluarga

Stres

\section{KEYWORDS:}

Work conflict

Family conflict

Stress

\section{CITATION:}

Muhammad Daniel Aidil et al. (2022). Perhubungan antara Konflik Kerja dan Keluarga terhadap Stres dalam kalangan Pekerja Kakitangan Awam. Malaysian Journal of Social Sciences and Humanities (MJSSH), 7(2), e001282.

https://doi.org/10.47405/mjssh.v7i2.1282

\begin{abstract}
ABSTRAK
Kajian ini adalah bertujuan untuk mengkaji hubungan antara konflik kerja dan konflik keluarga terhadap stres dalam kalangan pekerja kakitangan awam di Ibu Pejabat Polis Daerah Klang Selatan, Selangor, Malaysia. Soal kaji selidik yang digunakan adalah Perceived Stress Scale - 10 (PSS-10) dan Work-Family Conflict. Analisis kolerasi Pearson menunjukkan terdapat hubungan negatif yang signifikan antara konflik kerja dan konflik keluarga terhadap stres. Kajian ini telah mengesahkan bahawa konflik kerja dan konflik keluarga mampu mempengaruhi stres dalam kalangan responden bertepatan dengan keputusan hubungan yang signifikan antara konflik kerja dan konflik keluarga dengan stres. Hasil kajian juga mendapati perbezaan yang signifikan antara konflik kerja terhadap jantina, konflik kerja dan stres terhadap pendapatan. Manakala, untuk konflik keluarga menunjukkan perbezaan yang signifikan terhadap jumlah bilangan anak. Berdasarkan hasil dapatan kajian, penyelidik telah membincangkan beberapa cadangan untuk kajian yang akan dilakukan pada masa hadapan.
\end{abstract}

\section{ABSTRACT}

This study aims to examine the relationship between work conflict and family conflict against stress among civil 
servants at the South Klang District Police Headquarters, Selangor, Malaysia. The survey questions used were Perceived Stress Scale - 10 (PSS-10) and Work-Family Conflict. Pearson correlation analysis showed that there was a significant negative relationship between work conflict and family conflict with stress. This study has confirmed that work conflicts and family conflicts can influence stress among respondents coinciding with the results of a significant relationship between work conflicts and family conflicts with stress. The results of the study also found significant differences between work conflicts on gender, work conflicts and stress on income. Meanwhile, the family conflict shows a significant difference in the total number of children. Based on the findings of the study, researchers have discussed some suggestions for future research.

Sumbangan/Keaslian: Kajian ini adalah salah satu kajian yang telah mengkaji perhubungan antara konflik kerja dan keluarga terhadap stres dalam kalangan pekerja kakitangan awam. Sumbangan utama kajian ini ialah mendapati bahawa konflik kerja dan keluarga mempunyai hubungan signifikan dengan stres.

\section{Pengenalan}

Kerja dan keluarga merupakan komponen utama dalam kehidupan orang ramai dan dengan itu menuntut banyak masa dan tenaga dihabiskan untuk menguruskan pelbagai tanggungjawab. Walau bagaimanapun, pelbagai peranan yang perlu dipikul oleh individu meningkatkan konflik interpersonal dan intrapersonal dialami oleh wanita dan lelaki yang pada masa yang sama mengekalkan profesional dan peribadi tanggungjawab.

Stres merupakan sebahagian perkara yang tidak boleh dipisahkan dalam kehidupan seharian kita. Stres dari sudut bahasa membawa maksud tekanan di mana tekanan ini adalah fitrah manusia (Harussani, 2004). Stres juga merupakan faktor penyebab dan akibat daripada sesuatu penyakit sehingga tahap kesihatan seseorang individu menjadi rendah. Perkataan stres sebenarnya berasal daripada perkataan eustres yang membawa maksud dapat menyesuaikan diri atau stres yang membina. Stres juga berasal daripada perkataan distres yang bermaksud tidak dapat menyesuaikan diri ataupun dapat merosakkan diri. Jadi stres adalah merujuk kepada situasi yang mengganggu atau membina dalam kehidupan seharian (Fontana,1989).

Menurut Rice (1999), stres dapat didefinisikan berdasarkan tiga aspek iaitu pertama merujuk kepada rangsangan peristiwa atau persekitaran menjadi penyebab seseorang individu merasa tertekan. Kedua, stres merujuk kepada gerak balas subjektif dan ia juga dianggap sebagai faktor dalaman iaitu aspek mental dan yang ketiga ialah stres merujuk kepada reaksi fizikal tubuh badan dan cara mengatasi stres melalui kaedah tingkah laku dan psikologikal. Stres bagi setiap manusia adalah berbeza kerana setiap individu mempunyai persepsi, pengalaman hidup, keperibadian, dan sikap yang unik dan berbeza bagi setiap individu. Lahey (2001) mentakrifkan stres sebagai satu keadaan yang tidak selesa dan ancaman yang tidak sihat kepada seseorang individu. Keadaan stres yang teruk boleh menyebabkan keletihan, kemurungan dan pelbagai penyakit yang boleh menyebabkan kematian. 
Stres juga tidak dapat dipisahkan dengan pekerja. Pekerjaan pada zaman sekarang memerlukan seseorang yang kental dari segi fizikal dan juga emosi. Hal ini kerana stres boleh mempengaruhi tingkah laku dan emosi seseorang. Arus pemodenan dunia pada zaman sekarang menyebabkan beban kerja semakin bertambah. Keadaan ini boleh menimbulkan perasaan stres dalam diri pekerja secara langsung dalam memenuhi tuntutan aspek pekerjaan tidak kira kerja di luar atau dalam organisasi bergantung kepada keadaan individu tersebut. Oleh itu, sesetengah pekerja menggunakan rokok sebagai tempat mereka melepas tekanan yang mereka alami. Merokok merupakan salah satu kaedah "coping" yang digunakan dalam menghadapi stres. Menurut Lazarus dan Folkman (1984), "coping" adalah perubahan kognitif dan perilaku secara konstan dalam upaya untuk mengatasi tuntutan internal atau eksternal khusus yang melebihi sumber individu. Menurut Keliat (1999), mekanisme "coping" adalah cara yang dilakukan individu dalam menyelesaikan masalah, menyesuaikan diri dengan perubahan, serta respon terhadap situasi yang mengancam. Oleh yang demikian, strategi "coping" adalah cara untuk menyelesaikan masalah yang sedang dihadapi atau dirasakan.

\section{Penyataan Masalah}

Banyak kajian lepas telah membincangkan konflik dalam kalangan pekerja yang berada dalam pelbagai industri. Seperti contoh dalam bidang perhotelan (Hyun \& Young, 2012), bidang perubatan (Anafarta, 2011), bidang pendidikan (Boyar et al., 2008) dan lain-lain. Berikutan daripada kajian lepas ini, didapati bahawa konflik kerja dan keluarga ini merupakan salah satu punca yang menyebabkan seseorang itu menghadapi masalah keluarga dan di tempat kerja seperti tidak mendapat kepuasan hidup dan bekerja, prestasi kerja yang merosot, masalah pusing ganti kerja dan lain-lain.

Rakyat Malaysia tidak terkecuali mengalami gangguan kesihatan mental seperti stres. Dalam satu perbandingan ke atas dapatan kajian kesihatan dan morbiditi kebangsaan 1996, 2006 dan 2015 didapati statistik bagi kes gangguan kesihatan mental di Malaysia meningkat saban tahun. Malahan, masalah kesihatan mental juga menjadi semakin menular di peringkat global. Hasil kajian Tinjauan Kesihatan dan Morbiditi Kebangsaan pada tahun 2015 mendapati 29.2 peratus rakyat Malaysia mengalami tekanan atau masalah kesihatan mental. Ini bermaksud, tiga daripada 10 individu berusia 16 tahun ke atas mempunyai masalah kesihatan mental di mana wanita menunjukkan kadar yang sedikit tinggi berbanding lelaki. Selain itu, menurut keratan akhbar Harian Metro online bertarikh 03 Mei 2018 mengikut kaji selidik oleh rangkaian profesional LinkedIn, 32 peratus lelaki dan 29 peratus perempuan mengakui mereka mengalami tekanan pada usia 20-an dan 30-an. Kaji selidik terhadap 1,003 golongan muda Malaysia yang bekerja mendapati kira-kira satu pertiga daripada mereka rasa tertekan untuk berjaya dalam hubungan, kerjaya atau kewangan, walaupun majoriti kedua-dua jantina sudah mempunyai pekerjaan sepenuh masa.

Di samping itu, atas tekanan kerja dan permintaan keluarga yang mendesak, ada kalanya pekerja golongan belia gagal melaksanakan tanggungjawab mereka dengan sempurna. Ada juga dalam kalangan pekerja industri golongan belia yang sering terganggu kesihatan mereka akibat gagal menguruskan konflik dengan baik. Masalah konflik kerja dan keluarga terhadap stres yang dialami dalam kalangan pekerja ini merupakan satu isu yang harus dipandang serius dan menjadi tanggungjawab semua pihak untuk membendung masalah ini daripada semakin melarat. 


\section{Persoalan Kajian}

Secara khususnya, kajian ini bertujuan untuk mencari jawapan kepada persoalanpersoalan seperti berikut:-

i. Apakah profil latar belakang demografi pekerja kakitangan awam di Ibu Pejabat Polis Daerah Klang Selatan, Negeri Selangor?

ii. Apakah tahap konflik kerja, konflik keluarga dan stres dalam kalangan pekerja kakitangan awam di Ibu Pejabat Polis Daerah Klang Selatan, Negeri Selangor?;

iii. Adakah terdapat perkaitan antara konflik kerja dan konflik keluarga terhadap stres dalam kalangan pekerja kakitangan awam di Ibu Pejabat Polis Daerah Klang Selatan, Negeri Selangor?

iv. Adakah terdapat perbezaan di antara latar belakang demografi (umur, jantina, bangsa, bilangan anak, pendapatan) dengan konflik kerja, konflik keluarga dan stres dalam kalangan pekerja kakitangan awam di Ibu Pejabat Polis Daerah Klang Selatan, Negeri Selangor?

v. Apakah faktor-faktor konflik kerja dan konflik keluarga terhadap stres dalam kalangan pekerja kakitangan awam di Ibu Pejabat Polis Daerah Klang Selatan, Negeri Selangor?

\section{Objektif Kajian}

Objektif umum kajian ini adalah untuk mengkaji hubungan konflik kerja dan keluarga terhadap stres dalam kalangan pekerja kakitangan awam di Ibu Pejabat Polis Daerah Klang Selatan, Negeri Selangor. Untuk mencapai objektif umum ini, empat objektif khusus telah dibentuk, iaitu:

i. Untuk memerihalkan latar belakang demografi pekerja kakitangan awam di Ibu Pejabat Polis Daerah Klang Selatan, Negeri Selangor.

ii. Untuk mengkaji tahap konflik kerja, konflik keluarga dan stres dalam kalangan pekerja kakitangan awam di Ibu Pejabat Polis Daerah Klang Selatan, Negeri Selangor.

iii. Untuk mengenal pasti perkaitan antara konflik kerja dan konflik keluarga terhadap stres dalam kalangan pekerja kakitangan awam di Ibu Pejabat Polis Daerah Klang Selatan, Negeri Selangor.

iv. Untuk mengenal pasti perbezaan antara latar belakang demografi(umur, jantina, bangsa, bilangan anak, pendapatan) dengan konflik kerja, konflik keluarga dan stres dalam kalangan pekerja kakitangan awam di Ibu Pejabat Polis Daerah Klang Selatan, Negeri Selangor.

v. Untuk mengkaji faktor antara konflik kerja dan konflik keluarga terhadap stres dalam kalangan pekerja kakitangan awam di Ibu Pejabat Polis Daerah Klang Selatan, Negeri Selangor.

\section{Kerangka Konseptual}

\subsection{Definisi Konseptual dan Operasional}

\subsubsection{Konflik Kerja}

Definisi konseptual: Konflik Kerja atau Work Conflict adalah salah satu dari bentuk interrole conflict yang mana tekanan atau ketidakseimbangan peranan di tempat kerja (Greenhaus \& Beutell, 1985). Dalam konflik kerja, seseorang dapat mengalami konflik ini kerana tujuan yang saling bertentangan. Mereka merasakan ketidakfahaman dalam 
melakukan pekerjaan dengan baik. Persekitaran yang kurang memuaskan juga mampu menyebabkan konflik kerja.

Definisi operasional: Konflik biasanya berlaku dalam organisasi kerana hadirnya masalah. Sebagai contoh masalah komunikasi, masalah hubungan peribadi, atau struktur organisasi yang tidak terancang.

\subsubsection{Konflik Keluarga}

Definisi konseptual: Konflik keluarga digambarkan sebagai satu bentuk konflik antara dalam permintaan yang umum, masa yang terhad atau tidak teratur dan ketegangan yang dicipta oleh keluarga.

Definisi operasional: Kesalahan yang dilakukan dalam keluarga boleh menyebabkan terjadinya konflik dalam keluarga (seperti perbezaan pendapat, curang, masalah kewangan) dan jika dibiarkan perkara ini berlarutan ianya boleh mengakibatkan hancurnya rumah tangga dan keluarga.

\subsubsection{Stres}

Definisi konseptual: Menurut Lazarus dan Folkman (1984) stres adalah keadaan dalaman yang terhasil dari tuntutan fisiologi dari tubuh atau oleh pengaruh sosial yang membahayakan, tidak terurus atau melebihi kemampuan individu untuk melakukan kaedah penyesuaian. Menurut Selye (1976), stres terbahagi kepada dua iaitu :

i. Eustres merupakan pengalaman stres yang baik yang mana wujud ketika seseorang telah mendapat kejayaan dan kemenangan. Eustres dapat meningkatkan kesihatan mental, kewaspadaan, kognisi dan pencapaian individu.

ii. Manakala distres pula adalah pengalaman yang menyakitkan atau yang kurang menyenangkan yang bersifat mengancam. Hal demikian stres akan dirasai sebagai satu keadaan dimana individu mengalami perasaan cemas, takut, khuatir atau gelisah sehingga individu mengalami keadaan psikologi yang teruk.

Berdasarkan pandangan tokoh-tokoh tersebut pengertian stres dapat disimpulkan sebagai sebarang jenis desakan yang memberi kesan kepada kehidupan harian seseorang. Kesan daripada desakan ini mungkin baik atau buruk bergantung kepada tindak balas seseorang individu.

Definisi operasional: Stres berlaku akibat perubahan luaran atau dalaman yang melebihi kemampuan individu. (Luaran: konflik dalam hubungan, kematian, penceraian. Dalaman: Perasaan rendah diri, cemburu dan lain-lain). Dalam konteks kajian ini definisi stres yang digunakan adalah berdasarkan Cohen (1994) ialah Perceived Stress Scale iaitu bermaksud satu instrumen psikologikal untuk mengukur persepsi terhadap stres. Ia mengukur darjah keadaan dalam kehidupan seseorang dianggap sebagai sesuatu yang tertekan. Soalan dibina untuk menilai bagaimana sesuatu yang tidak boleh dijangka, tidak boleh dikawal dan lebihan tekanan yang responden kenal pasti dalam hidup mereka.

Rajah 1 di bawah merupakan kerangka konseptual kajian yang merangkumi pemboleh ubah terdahulu, pemboleh ubah tidak bersandar dan pemboleh ubah bersandar yang mendasari kajian ini. 
Rajah 1: Kerangka konseptual kajian

Pemboleh ubah Terdahulu

\section{Pemboleh ubah Tidak Bersandar}

\section{Pemboleh ubah} Bersandar

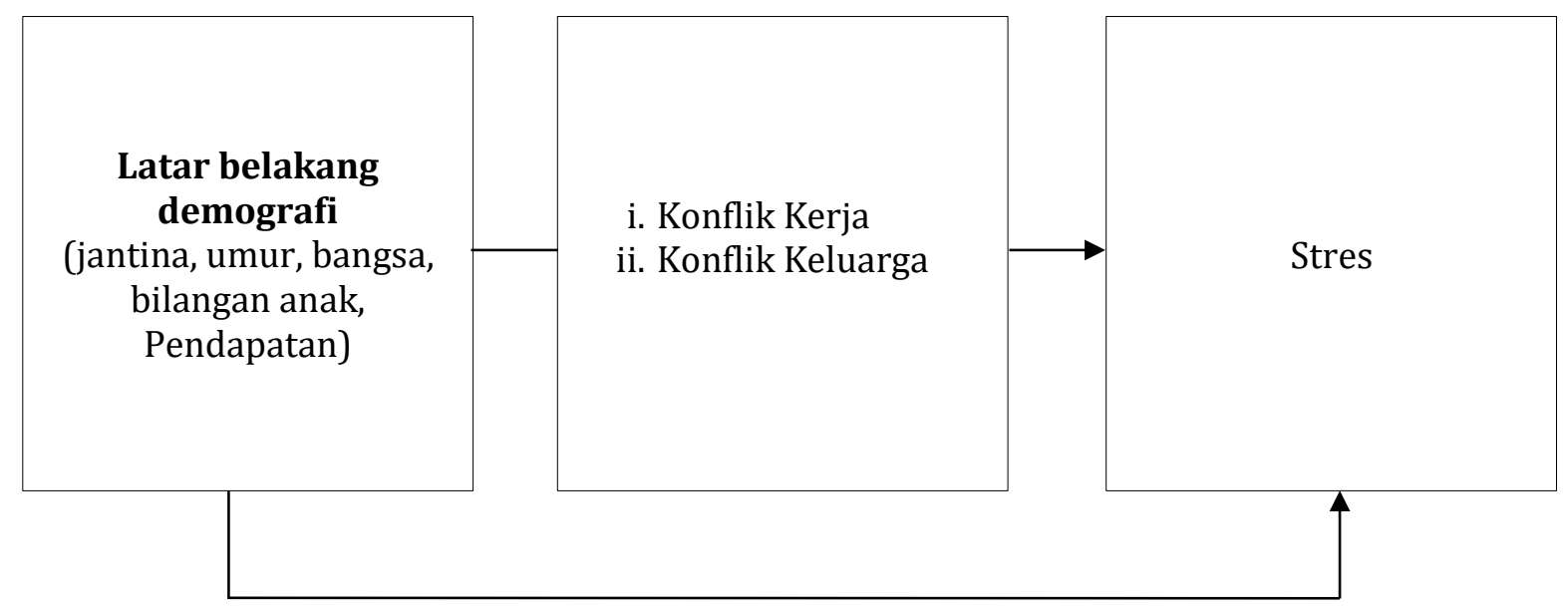

\section{Kajian Literatur}

\subsection{Konflik Kerja}

Dalam bekerja hampir setiap orang mempunyai tekanan yang berkaitan dengan pekerjaan mereka. Menurut Khashimah (2014), tekanan kerja atau stres kerja ini adalah suatu keadaan yang muncul akibat daripada interaksi antara individu dengan pekerjaan dan persekitaran mereka, ini bermaksud terdapat percanggahan ciri-ciri dan perubahan-perubahan yang tidak jelas yang berlaku dalam sesebuah organisasi itu. Konflik kerja menurut Kahn dan Quiin (1970) merupakan proses yang kompleks, sering berubah, dan dinamik dimana stressor, pandangan tentang tekanan itu sendiri, respon singkat, kesan kesihatan, dan perubahan variabelnya saling berkait. Manakala Selye (1976) mengatakan bahawa tekanan kerja ini boleh ditakrifkan sebagai faktor atau stressor kerja yang menyebabkan reaksi individu itu berupa reaksi fisiologi, psikologi, dan tingkah laku seseorang.

Definisi konflik kerja menurut Morgan et al. (1986) adalah suatu keadaan yang bersifat dari dalaman, yang boleh disebabkan oleh aspek fizikal atau persekitaran, dan situasi sosial yang berpeluang merosakkan dan tidak terkawal. Cooper (1994) juga menyatakan bahawa stres kerja juga ditakrifkan sebagai tanggapan atau proses dalaman atau luaran yang menyumbang tahap ketegangan fizikal dan psikologi sampai pada tahap atau melebihi tahap kemampuan pegawai. Seterusnya, oleh Putra et al. (2016) dimana kajian membuktikan bahawa beberapa sumber stres di sebuah organisasi merangkumi beban kerja yang berlebihan, pengawasan yang tidak mencukupi, kekaburan peranan dan kurangnya pengiktirafan. Tekanan kerja akan memberi impak ketara dari segi produktiviti rendah, pekerja yang sakit, dan pengurusan masa yang tidak teratur. Pernyataan ini menunjukkan bahawa tekanan yang berlebihan membawa kepada perubahan tingkah laku, secara psikologi dan emosi pekerja sehingga boleh mengganggu prestasi merangkumi kualiti dan kuantiti kerja yang kurang memuaskan. 
Putra et al. (2014) juga menyatakan bahawa terdapat beberapa keadaan kerja yang sering menimbulkan tekanan kepada pekerja, antaranya seperti, beban kerja yang berlebihan, tekanan waktu atau tekanan situasi, kualiti pengawasan yang buruk, iklim politik atau situasi di organisasi yang tidak selamat, maklum balas mengenai prestasi kerja yang tidak mencukupi, kekuatan yang tidak mencukupi untuk melaksanakan tanggungjawab, kekaburan peranan, kekecewaan, konflik antara individu dan antara kumpulan, perbezaan antara nilai syarikat dan pekerja, dan pelbagai bentuk perubahan. Kajian lepas iaitu kajian Masilamani et al. (2013) serta Nursyazlin dan Noraini (2017) juga mendapati bahawa anggota polis yang berpangkat Inspektor lebih mengalami stres berbanding anggota polis yang lain kerana faktor tanggungjawabnya yang besar dalam sudut penyiasatan kes, tugas-tugas khas, jenayah komersil, operasi khas (seperti membendung jenayah serta keganasan) dan jenayah narkotik. Ini menunjukkan bahawa faktor pendapatan yang diperoleh menjadi faktor kepada tekanan dan konflik kerja yang dihadapi oleh anggota polis. Anggota polis yang berpendapatan tinggi lazimnya adalah daripada kalangan mereka yang berjawatan besar dan penting dalam organisasi. Semakin tinggi jawatan yang disandang, semakin tinggilah masalah dan konflik yang akan mereka tempuhi. Kajian lepas juga mendapati bahawa konflik kerja seperti tugasan kerja yang banyak atau terpaksa bekerja lebih masa merupakan punca utama stres (Brinson \& Benoit, 1999).

Menurut kajian Thi (1998) pula, hasil kajiannya menunjukkan pengurus dan eksekutif perempuan mengalami konflik kerja yang lebih tinggi berbanding dengan pengurus dan eksekutif lelaki. Begitu juga menurut Adkins dan Premeaux (2012) ada jangkaan yang berkaitan dengan peranan tertentu (pekerjaan) dan harapan itu menyebabkan individu gagal memenuhi tanggungjawab peranan lain (keluarga), ini menyebabkan prestasi peranan yang lemah dan membawa kepada konflik keluarga sejurus mengundang stres. Konflik kerja dan keluarga adalah konflik antara peranan yang berlaku kepada individu akibatnya ketidakupayaan untuk membahagikan dua peranan tersebut (Netemeyer et al., 1996). Saat ini, semakin ramai pekerja yang merasa sukar untuk mengimbangkan tuntutan antara kerja dan tanggungjawab dalam keluarga, sehingga mendorongnya konflik antara pekerjaan dan kehidupan keluarga (Alazzam et al., 2017). Selain itu, menurut Seery et al. (2008) konflik keluarga dan kerja adalah konstruk dua arah yang menggambarkan dua jenis konflik yang berbeza, iaitu konflik kerja terhadap keluarga (kerja mengganggu kehidupan keluarga) dan konflik keluarga terhadap kerja (keluarga mengganggu tanggungjawab kerja). Secara konseptual, kedua konflik ini adalah konflik antara peranan. Oleh yang demikian garis besar dapat dikatakan bahawa konflik keluarga dan kerja mempengaruhi kehidupan keluarga termasuk kepuasan dan prestasi dalam keluarga. Manakala konflik kerja dan keluarga akan memberi kesan kepada ketidakpuasan kerja, kelambatan, prestasi rendah. Isu mengenai konflik pekerjaan dan keluarga menjadi keprihatinan terhadap organisasi kerana penyelidikan menunjukkan bahawa konflik kerja dan keluarga ini mempunyai kesan terhadap penurunan prestasi pekerja (Yavas et al., 2008).

\subsection{Konflik Keluarga}

Beberapa peneliti terdahulu mengatakan Work Family Conflict (WFC) dapat berpengaruh pada stres kerja. Hal ini sesuai dengan penelitian yang dilakukan oleh Indriyani (2009) serta Agustina dan Sudibya (2018). yang mengatakan semakin tinggi konflik pekerjaan keluarga ini, maka semakin tinggi stres kerja yang akan dihadapi oleh individu tersebut. Hubungan antara konflik keluarga kerja terhadap tekanan kerja adalah sesuai dengan kajian Karabaya et al. (2013) yang mengatakan bahawa konflik 
keluarga dan kerja mempengaruhi beban kerja, persekitaran dan peranan kerja yang buruk. Kazmi et al. (2017) juga mengatakan bahawa masalah pekerjaan dan keluarga ini perlu dipandang tinggi dan tidak ambil mudah bagi individu dan dalam sebuah organisasi, kerana kesannya yang negatif dan buruk. Hasil kajiannya juga menunjukkan bahawa tekanan kerja adalah sangat tinggi berkaitan dengan konflik keluarga dan kerja seseorang. Kesimpulan dan Cadangan dari penyelidikannya menunjukkan bahawa, Pihak atasan atau majikan dalam organisasi perlulah memberi sokongan kepada pekerja, mengenal pasti masalah dan berkomunikasi dengan baik bersama kakitangannya, dalam mengatasi masalah tekanan pada pekerja.

Konflik kerja dan keluarga adalah konflik antara peranan yang berlaku kepada individu akibatnya ketidakupayaan untuk membahagikan dua peranan tersebut (Netemeyer et al., 1996). Saat ini, semakin ramai pekerja yang merasa sukar untuk mengimbangkan tuntutan antara kerja dan tanggungjawab dalam keluarga, sehingga mendorongnya konflik antara pekerjaan dan kehidupan keluarga (Alazzam et al., 2017). Novianti (2015), hasil kajiannya menunjukkan bahawa jika ada Work Family Conflict (WFC) yang dialami oleh pekerja dengan Psychological Capital (modal psikologi) rendah, ia boleh meningkatkan tekanan kerja seseorang. Hasil kajian ini dapat digunakan untuk membantu pekerja memperbaiki potensi dalam diri mereka dengan bersedia untuk mengatasi masalah yang timbul hasil dari bebanan di tempat kerja dan tanggungjawab keluarga. Seterusnya, Lu Yong et al. (2017), waktu tambahan masa kerja yang diberikan oleh pekerja juga akan memberikan tekanan dalam diri, di mana ia harus meluangkan lebih banyak masa di pejabat berbanding dengan keluarga, dan juga mereka akan lebih cepat mengalami keletihan dan membawa kepada masalah stres.

Asfahyadin et al. (2017) mengatakan bahawa Konflik Keluarga terhadap Pekerjaan mempunyai kesan positif yang signifikan terhadap prestasi pekerja. Dengan kata lain, semakin tinggi konflik yang dihadapi terhadap pekerja, semakin rendah prestasinya. Ini bermaksud bahawa dengan meminimumkan dan menjangkakan masalah Konflik Keluarga dengan baik, akan ada peningkatan prestasi pekerja sejurus dapat mengatasi masalah stres. Simunic dan Gregove (2012) dalam dapatan kajiannya turut mengatakan bahawa persepsi terhadap konflik keluarga akan memberi kesan kepada kepuasan hidup dalam kalangan jururawat. Maka, ianya dapat disimpulkan di sini bahawa konflik keluarga yang berlaku akan cenderung memberi kesan negatif kepada banyak aspek dalam kehidupan contohnya seperti keletihan, waktu tidur tidak menentu, hubungan sosial dan keluarga berkurang dan potensi diri juga turut menurun.

Selain itu, menurut Asmaningrum et al. (2014) dan Zaharah et al. (2017) dimana dapatan hasil kajiannya mendapati bahawa sebuah keluarga mempunyai kesan yang positif terhadap menyelesaikan konflik atau kekangan yang dihadapi oleh ahli keluarga dengan hanya meluangkan masa dan menjadi pendengar sahaja. Daripada perspektif keluarga, kajian lepas mendapati pasangan yang berkahwin mengalami konflik yang tinggi berbanding yang masih bujang (Grzywacz et al., 2002). Manakala pasangan yang mempunyai anak juga dilaporkan mengalami konflik yang tinggi berbanding dengan pasangan yang tidak mempunyai anak. Selain itu, Apperson et al. (2002) menyatakan bahawa konflik keluarga boleh berlaku pada lelaki dan wanita. Walau bagaimanapun, beberapa kajian menunjukkan bahawa wanita yang lebih tua cenderung mengalami konflik keluarga berbanding lelaki. Ini disebabkan oleh tanggungjawab wanita khususnya yang sudah berkahwin dan tidak bekerja, mereka perlu melakukan kerja rumah dan menjadi isteri atau suri rumah. 


\subsection{Stres}

Stres adalah tindak balas emosi yang buruk kerana perubahan yang berlaku dari dalaman atau luaran (Ibrahim, 1998). Menurut McShane dan Von Glinow (2000), stres adalah tindak balas adaptif terhadap situasi yang dianggap sebagai cabaran atau ancaman terhadap kesihatan seseorang. Tindak balas adaptif seseorang dapat dilihat dari reaksi psikologi (emosi) dan fizikal (fisiologi). Kajian Robbins (2006) dan Darmawan (2018) mengatakan bahawa stres dapat ditakrifkan sebagai suatu keadaan dinamik dimana seseorang individu berhadapan dengan suatu peluang iaitu kekangan (constrain), tuntutan (demand) atau sumber daya yang berkaitan dengan apa juga kemahuannya dan hasilnya dipersepsikan sebagai suatu yang tidak pasti dan tidak penting. Imani et al. (2018) mengatakan bahawa work family conflict berpotensi membawa kepada stres kerja kerana ketika urusan pekerjaan yang melibatkan kehidupan keluarga, maka tekanan atau stres sering kali terjadi kepada individu itu, disebabkan ketidakseimbangan pengurusan waktu yang dihabiskan dalam pekerjaan dan masa yang perlu disediakan lebih banyak untuk keluarga. Tekanan yang negatif, baik dari segi mental, fizikal atau emosi, merupakan satu faktor penting yang boleh menggugat keharmonian kualiti kehidupan seseorang pekerja Tekanan yang negatif, baik dari segi mental, fizikal atau emosi, merupakan satu faktor penting yang boleh menggugat keharmonian kualiti kehidupan seseorang pekerja (Ganing et al., 2020).

Khashimah (2014) berpendapat bahawa faktor dan kesan negatif organisasi, ekonomi dan individu adalah merupakan sumber-sumber yang berpotensi dalam memberikan tekanan atau stres dalam hidup pekerja. Faktor ekonomi termasuklah ketidakseimbangan ekonomi, politik dan sosial. Sementara faktor organisasi merangkumi aspek tuntutan-tuntutan kerja, peranan interpersonal, struktur dalam organisasi dan kepimpinan organisasi. Faktor individu pula termasuklah komitmen diri (pendapatan kerja, perkahwinan) dan lain-lain. Penekanan semua aspek ini mewujudkan pengalaman tekanan dan stres di kalangan individu. Jika individu tidak berjaya menangani tekanan tersebut, maka individu akan mengalami petanda fisiologi dan petanda tingkah laku yang negatif. Petanda fisiologi termasuklah sakit kepala, demam, tekanan darah tinggi dan sakit jantung. Petanda psikologi pula merangkumi aspek kebimbangan, ketegangan dan kekurangan kepuasan kerja sementara petanda tingkah laku pula termasuk prestasi diri yang rendah dan ketidakhadiran bekerja.

Berdasarkan kajian lepas, menurut penelitian Rajak (2013) bahawa sumber utama dari stres setiap diri individu adalah dari konflik pekerjaan dan permintaan keluarga. Stres adalah proses psikologi yang tidak menyenangkan yang berlaku sebagai tindak balas terhadap tekanan persekitaran. Ini menunjukkan bahawa pekerja yang dapat mengurangkan stres sudah tentu akan hidup dalam keadaan tenang, bahagia dan harmoni. Menurut kajian yang dijalankan oleh Md Safian (2007) mengatakan bahawa stres sebenarnya mempunyai impak negatif terhadap kesihatan pekerja seperti sakit kepala, penyakit kardiovaskular dan sebagainya, terhadap psikologikal iaitu kemurungan, rasa rendah diri, "burn-out" dan terhadap tingkah laku pekerja seperti penyalahgunaan dadah dan merokok serta terhadap organisasi seperti ketidakhadiran, turnover serta produktiviti yang rendah.

Berdasarkan kepada kepentingan kesihatan dan juga hubungannya dengan produktiviti yang telah dijelaskan di atas maka kajian ini dijalankan bagi melihat keperluankeperluan pekerja dalam aspek kesihatan dan status kesihatan pekerja dalam situasi sebenarnya. Kajian tersebut bertujuan untuk mengenal pasti kesan aspek kesihatan 
terhadap produktiviti kerja pensyarah maktab perguruan di Semenanjung Malaysia. Persoalan kajian cuba mengenal pasti kesan aspek kesihatan terhadap produktiviti serta perbezaan antara demografi dan pemboleh ubah yang dikaji. Subjek kajian adalah seramai 204 orang pensyarah lelaki dan perempuan yang mengajar di tiga buah maktab perguruan di Semenanjung Malaysia. Kajian tersebut mendapati bahawa terdapat kesan yang signifikan dalam fungsi fizikal dan kesihatan mental terhadap produktiviti dalam kalangan pensyarah maktab perguruan.

Dapatan kajian juga mendapati bahawa pensyarah lelaki lebih baik daripada pensyarah perempuan dalam aspek fungsi fizikal dan fungsi sosial. Dari aspek kesihatan mental dan tahap produktiviti pula, kajian ini mendapati tidak terdapat perbezaan signifikan antara pensyarah lelaki dan pensyarah perempuan. Kajian juga mendapati kumpulan pensyarah yang berumur kurang daripada 40 tahun lebih baik daripada kumpulan pensyarah berumur 41 - 49 tahun dan berumur melebihi 50 tahun dalam aspek produktiviti dan fungsi fizikal. Selain itu, dapatan menarik mendapati kumpulan pensyarah berumur kurang daripada 41 - 49 tahun lebih baik daripada kumpulan pensyarah berumur kurang daripada 40 tahun dan pensyarah berumur melebihi 50 tahun dalam aspek kesihatan mental. Selain itu, pensyarah berumur melebihi 50 tahun didapati lebih baik dalam aspek fungsi sosial jika dibandingkan dengan dua lagi kumpulan umur yang dikaji.

Manakala, menurut Imani et al. (2018) mengatakan bahawa work family conflict berpotensi membawa kepada stres. Selain itu, dalam jurnal artikel hubungan antara stres kerja dan upah terhadap produktiviti kerja, penulis Handoko (2008) dan Junike, Lery Fransil dan Harvani (2018) menunjukkan bahawa Stres adalah suatu kondisi ketegangan yang mempengaruhi emosi, proses berpikir, dan kondisi seseorang. McShane dan Von Glinow (2005) juga turut menyatakan stres adalah tindak balas adaptif terhadap situasi yang dianggap sebagai cabaran atau ancaman terhadap kesihatan seseorang. Terakhir dalam jurnal artikel yang bertajuk Pengaruh Work Family Conflict Terhadap Stres Kerja dan Kepuasan Kerja, penulis, Metta Astari dan Adnyan (2018) menjelaskan bahawa tekanan adalah proses psikologi perkara tidak menyenangkan yang berlaku sebagai tindak balas terhadap tekanan persekitaran. Kajian oleh Hammer et al. (2004), Bazana dan Dodd (2013) serta Indriyani (2009) dalam penelitiannya mengatakan "semakin tinggi konflik kerja dan konflik keluarga, maka semakin tinggi pula stres yang dihadapi oleh pekerja. Seterusnya berdasarkan kajian Agustina dan Sudibya (2018) pula, yang menunjukkan terdapat hubungan yang signifikan antara konflik kerja dan konflik keluarga terhadap stres dengan nilai $\mathrm{p}<0.05$.

\section{Metod Kajian}

Reka bentuk kajian ini adalah berbentuk kuantitatif di mana penyelidik akan melibatkan analisis deskriptif dan inferensi. Kajian ini dijalankan di sebuah organisasi dan organisasi yang dipilih ialah di Ibu Pejabat Polis Daerah Klang Selatan, Negeri Selangor. Lokasi kajian dipilih dalam kalangan kaki tangan awam di Ibu Pejabat Polis Daerah Klang Selatan, Selangor kerana pekerjaan yang melibatkan keselamatan atau keamanan negara merupakan pekerjaan yang agak sukar untuk diselesaikan atau di atasi sekiranya tidak dapat dikawal dan dirancang dengan sangat baik. Maka, jika tidak dapat menguruskan masa di tempat kerja dan bersama keluarga dengan betul, ianya boleh mendatangkan stres atau tekanan kepada pekerja itu sendiri. Lebih-lebih lagi pekerja kakitangan awam polis yang memiliki gred jawatan rendah, contohnya Gred Konstabel, Lans Koperal dan Sarjan. Malah, kira-kira 25 peratus daripada 1.6 juta penjawat awam 
di negara ini mengalami tekanan kerja (Astro Awani, 2019). Menurut Datuk Azih Muda, Presiden Kongres Kesatuan Pekerja dalam Perkhidmatan Awam, penjawat awam yang berkhidmat di sektor kesihatan, pendidikan dan keselamatan juga antara berisiko tinggi mengalami stres disebabkan tekanan kerja.

Dalam kajian ini, penyelidik memilih populasi yang bersesuaian dengan kajian yang ingin dijalankan iaitu seramai 257 orang Kakitangan. Populasi kajian ini terdiri daripada pekerja dari sektor awam iaitu anggota polis. Populasi ini juga terdiri daripada responden yang bekerja dan mempunyai keluarga.

Penentuan saiz sampel dalam kajian ini adalah berasaskan kepada persampelan rawak mudah. Ia dilakukan dengan menggunakan kaedah memilih sampel daripada populasi dari senarai yang banyak dengan menggunakan jadual nombor rawak. Berdasarkan kepada Krejcie dan Morgan (1970), bagi bilangan populasi seramai 257 orang, sampel yang diperlukan adalah sekurang-kurangnya seramai 155 orang.

\subsection{Instrumen Kajian}

Set soal selidik kajian ini dibahagikan kepada empat (3) seperti yang diringkaskan pada Jadual 1 dibawah:

Jadual 1: Kandungan Borang Soal Selidik

\begin{tabular}{llll}
\hline Bahagian & Item & $\begin{array}{l}\text { Bilangan } \\
\text { Item }\end{array}$ & Pemboleh ubah \\
\hline A & Umur & 1 & Terdahulu \\
& Bangsa & 1 & \\
& Jantina & 1 & \\
& Bilangan Anak & 1 & Tidak Bersandar \\
& Pendapatan & 1 & \\
B & Konflik kerja & 13 & Bersandar \\
& Konflik keluarga & 13 & \\
C & Stres & 12 & \\
\hline Jumlah & & 43 & \\
\hline
\end{tabular}

\subsubsection{Maklumat Peribadi}

Bahagian ini bertujuan untuk mengumpul maklumat berkaitan latar belakang responden. Sebanyak lima (5) soalan dikemukakan kepada responden yang merangkumi umur, bangsa, jantina, bilangan anak, dan pendapatan.

\subsubsection{Aspek Mempengaruhi Konflik Kerja dan Konflik Keluarga}

Bahagian ini telah diadaptasi daripada borang soal selidik yang telah diterbitkan oleh Khashimah (2014) iaitu "Tekanan kerja di kalangan kakitangan awam". Soal selidik bagi domain Konflik Kerja mengandungi 13 item soalan berkaitan dengan aspek mempengaruhi kepuasan kerja iaitu Konflik Kerja. Bagi domain Konflik Kerja, pengkaji telah menggabungkan ayat mengikut kesesuaian soalan dan telah menambah sebanyak enam (6) item seperti butiran di bawah supaya pemboleh ubah tidak bersandar iaitu konflik kerja dapat diukur dengan lebih tepat. 
Pernyataan 1 : Sentiasa bersemangat dan berkeyakinan dalam menyelesaikan tugasan yang diberikan

Pernyataan 2 : Tugasan kerja yang setaraf dengan kebolehan dan jawatan yang saya perolehi

Pernyataan 3 : Sentiasa bersemangat dan berkeyakinan dalam menyelesaikan tugasan yang diberikan

Pernyataan 4 : Saya berasa gembira dengan tugasan yang saya lakukan

Pernyataan 5 : Saya dapat melakukan tugasan kerja dengan baik tanpa sebarang gangguan sama ada dari aspek persekitaran (contoh: rakan kerja, tempat yang bersih/tenang, dll...)

Pernyataan 6 : Pendapatan yang saya terima adalah sangat baik dan cukup untuk menampung kehidupan/komitmen saya

Jadual 2 menunjukkan 13 item yang digunakan untuk mengukur Konflik Kerja:

Jadual 2: Item Konflik Kerja

\begin{tabular}{|c|c|c|}
\hline No. & Penyataan & Item \\
\hline 1 & $\begin{array}{l}\text { Sentiasa bersemangat dan berkeyakinan dalam menyelesaikan tugasan yang } \\
\text { diberikan }\end{array}$ & Positif \\
\hline 2 & Saya boleh menjalankan bidang tugasan yang lain/pelbagai & Positif \\
\hline 3 & Saya dapat menyiapkan tugasan/kerja pada masa yang ditetapkan & Positif \\
\hline 4 & Agihan kerja yang relevan dengan skop kerja yang disandang & Positif \\
\hline 5 & Saya berasa gembira dengan tugasan yang saya lakukan & Positif \\
\hline 6 & $\begin{array}{l}\text { Tugasan kerja yang diberikan adalah mudah dan saya dapat melakukan } \\
\text { dengan baik }\end{array}$ & Positif \\
\hline 7 & $\begin{array}{l}\text { Tugasan kerja yang setaraf dengan kebolehan diri dan jawatan yang saya } \\
\text { perolehi }\end{array}$ & Positif \\
\hline 8 & $\begin{array}{l}\text { Saya dapat melakukan tugasan kerja dengan baik tanpa sebarang gangguan } \\
\text { sama ada dari aspek persekitaran (contoh ; rakan kerja, tempat yang } \\
\text { bersih/tenang, dll...) }\end{array}$ & Positif \\
\hline 9 & $\begin{array}{l}\text { Pandangan atau pendapat yang saya berikan sering didengari dan diterima } \\
\text { oleh pihak atasan }\end{array}$ & Positif \\
\hline 10 & Saya memiliki rakan kerja yang bersefahaman dan bekerjasama & Positif \\
\hline 11 & $\begin{array}{l}\text { Rakan kerja saya sentiasa memberi pertolongan dan pendapat jika saya } \\
\text { memerlukan }\end{array}$ & Positif \\
\hline 12 & Selalu diarahkan bekerja lebih masa dan masa saya tidak terurus & Negatif \\
\hline 13 & $\begin{array}{l}\text { Pendapatan yang saya terima adalah sangat baik dan cukup untuk } \\
\text { menampung kehidupan/komitmen saya }\end{array}$ & Positif \\
\hline
\end{tabular}

Manakala bagi domain konflik keluarga pula diadaptasi daripada borang soal selidik oleh Noor Adilah (2013). Soalan asal berkaitan konflik keluarga dalam soal selidik yang diadaptasi ini mengandungi enam (6) item sahaja. Namun, pengkaji telah mengubah suai dan menambah sebanyak tujuh (7) item seperti butiran di bawah supaya pemboleh ubah tidak bersandar iaitu Konflik keluarga dapat diukur dengan lebih tepat. Oleh itu, secara keseluruhannya sebanyak 13 item soalan telah dikemukakan untuk mengukur prestasi kerja dalam kalangan responden.

Pernyataan 1 : Semasa saya bersama keluarga di rumah, saya tidak terganggu dan membawa hal lain bersama keluarga saya

Pernyataan 2 : Saya tidak berasa tertekan apabila berjumpa dengan keluarga

Pernyataan 3 : Keluarga saya sentiasa memberi sokongan dan dorongan kepada saya apabila saya menghadapi masalah

Pernyataan 4 : Saya sentiasa meluangkan masa bersama keluarga dengan baik

Pernyataan 5 : Keluarga saya adalah keutamaan bagi saya 
Pernyataan 6 : Saya sentiasa memberi kerjasama yang baik terhadap keluarga

Pernyataan 7 : Keluarga saya sangat memahami perasaan saya dan lebih berfikiran terbuka

Jadual 3 pula merupakan senarai 13 item yang digunakan untuk mengukur Konflik Keluarga:

Jadual 3: Item Konflik Keluarga

\begin{tabular}{lll}
\hline No. & Penyataan & Item \\
\hline 1 & $\begin{array}{l}\text { Saya akan pulang ke rumah dalam keadaan yang gembira untuk berjumpa } \\
\text { dengan keluarga }\end{array}$ & Positif \\
2 & $\begin{array}{l}\text { Saya tidak berasa tertekan apabila berjumpa dengan keluarga } \\
3\end{array}$ & Keluarga saya sering memarahi saya di atas setiap tindakan saya \\
4 & Saya berasa terpinggir apabila berada dengan keluarga & Positif \\
5 & Kadang kala, Saya berasa cemburu dengan ahli keluarga saya yang lain & Negatif \\
6 & Keluarga saya selalu menolak idea dan pendapat saya. & Negatif \\
7 & Saya berasa selesa ketika berkomunikasi dengan keluarga saya \\
8 & Semasa saya bersama keluarga dirumah, saya tidak terganggu atau membawa & Negatif \\
& hal lain bersama keluarga saya & Positif \\
9 & $\begin{array}{l}\text { Keluarga saya sentiasa memberi sokongan dan dorongan kepada saya apabila } \\
\text { saya menghadapi masalah }\end{array}$ & Positif \\
10 & Saya sentiasa meluangkan masa bersama keluarga dengan baik & \\
11 & Keluarga saya adalah keutamaan bagi saya & Positif \\
12 & Saya sentiasa memberi kerjasama yang baik terhadap keluarga & Positif \\
13 & Keluarga saya sangat memahami perasaan saya dan lebih berfikiran terbuka & Positif \\
\hline
\end{tabular}

\subsubsection{Stres}

Domain stres diadaptasi daripada borang soal selidik oleh Noor Adilah (2013). Soalan asal berkaitan perasaan stres konflik kerja dan keluarga dalam soal selidik yang diadaptasi ini mengandungi 10 item sahaja. Namun, pengkaji telah menambah sebanyak dua (2) item soalan seperti butiran di bawah supaya pemboleh ubah bersandar iaitu perasaan (stres) dapat diukur dengan lebih tepat. Oleh itu, secara keseluruhannya sebanyak 12 item soalan telah dikemukakan untuk mengukur perasaan dalaman dan emosi dalam kalangan responden.

Pernyataan 1 : Dalam tempoh sebulan yang lalu, anda berasa tidak suka untuk berhadapan dengan orang sekeliling?

Pernyataan 2 : Dalam tempoh sebulan yang lalu, anda berasa hampa serta kecewa dengan prestasi diri anda?

Jadual 4 meringkaskan senarai item-item dalam borang soal selidik yang digunakan untuk mengukur Stres:-

Jadual 4: Item Konflik Keluarga

\begin{tabular}{lll}
\hline No. & Penyataan & Item \\
\hline 1 & $\begin{array}{l}\text { Dalam tempoh sebulan yang lalu, anda berasa sedih disebabkan sesuatu yang } \\
\text { anda tidak jangka berlaku? }\end{array}$ & Negatif \\
2 & $\begin{array}{l}\text { Dalam tempoh sebulan yang lalu, anda merasakan bahawa anda tidak mampu } \\
\text { untuk mengawal perkara-perkara penting dalam hidup anda? }\end{array}$ & Negatif \\
3 & $\begin{array}{l}\text { Dalam tempoh sebulan yang lalu, anda merasa gementar dan tertekan? } \\
\text { Dalam tempoh sebulan yang lalu, anda merasa yakin tentang kebolehan anda } \\
\text { untuk mengawal masalah peribadi anda? }\end{array}$ & Negatif \\
\hline
\end{tabular}


$5 \quad$ Dalam tempoh sebulan yang lalu, anda merasakan perkara-perkara yang

Positif berlaku mengikut seperti yang dirancang?

6 Dalam tempoh sebulan lalu, anda mendapati diri anda tidak berdaya

Negatif menguruskan dengan perkara-perkara yang anda perlu lakukan?

7 Dalam tempoh sebulan lalu, anda mampu mengawal perkara yang

Positif menyakitkan hati dalam hidup anda?

8 Dalam tempoh sebulan yang lalu, anda merasakan yang anda berjaya

Positif mengawal semua keadaan yang berlaku pada diri anda?

9 Dalam tempoh sebulan yang lalu, anda telah merasa marah kerana perkara- $\quad$ Negatif perkara yang berlaku di luar kawalan anda?

10 Dalam tempoh sebulan yang lalu, anda merasa kesusahan yang teramat sangat Negatif menimpa diri anda sehinggakan anda tidak dapat menyelesaikannya?

11 Dalam tempoh sebulan yang lalu, anda berasa tidak suka untuk berhadapan Negatif dengan orang sekeliling?

12 Dalam tempoh sebulan yang lalu, anda berasa hampa serta kecewa dengan Negatif prestasi diri anda?

Bagi bahagian B dan C, responden diminta untuk memilih jawapan berdasarkan kepada skala likert. Terdapat lima jenis skala likert yang digunakan seperti ditunjukkan dalam Jadual 5. Responden perlu memilih salah satu daripada jenis skala tersebut.

Jadual 5: Skala Likert bagi Bahagian B dan C

\begin{tabular}{ccc}
\hline Pernyataan & Ringkasan & Skor \\
\hline Sangat Setuju & SS & 5 \\
Setuju & S & 4 \\
Tidak pasti & TP & 3 \\
Tidak Setuju & TS & 2 \\
Sangat Tidak Setuju & STS & 1 \\
\hline
\end{tabular}

Data yang diperoleh telah dianalisis dengan menggunakan perisian Statistical Package for the Social Sciences (SPSS) version 21. Penggunaan perisian ini membolehkan data dianalisis dengan mudah dan cepat serta mendapatkan data yang tepat mengikut objektif kajian. Penganalisisan data dijalankan melalui dua tahap iaitu univariat (statistik deskriptif) dan bivariat (ujian korelasi Pearson, ujian $t$ atau ujian anova) (Jadual 6).

Statistik deskriptif digunakan bagi menjawab objektif yang pertama, kedua dan ketiga iaitu untuk memerihalkan latar belakang demografi kakitangan awam, mengkaji faktor antara konflik kerja dan konflik keluarga terhadap stres serta mengkaji tahap konflik kerja, konflik keluarga dan stres kakitangan awam. Data dipersembahkan dalam bentuk nilai kekerapan (f), nilai peratusan (\%) serta nilai purata (mean). Selain itu, ujian korelasi Pearson pula digunakan untuk menentukan perkaitan antara dua pemboleh ubah iaitu pemboleh ubah tidak bersandar (konflik kerja dan keluarga) dan pemboleh ubah bersandar (stres) serta menguji hipotesis- hipotesis yang dibina. Seterusnya bagi menjawab objektif kelima, ujian $\mathrm{t}$ dan anova digunakan. Ujian $\mathrm{t}$ digunakan untuk mengenal pasti perbezaan antara jantina dengan konflik kerja, manakala ujian anova digunakan untuk mengenal pasti perbezaan di antara latar belakang demografi (jantina, umur, bangsa, bilangan anak dan pendapatan) dengan konflik kerja, konflik keluarga dan stres. Jadual 6 menunjukkan kaedah analisis data secara terperinci yang digunakan untuk mencapai objektif kajian yang telah ditetapkan. 


\section{Objektif}

1. Untuk memerihalkan latar belakang demografi pekerja kakitangan awam di Ibu Pejabat Polis Daerah Klang Selatan, Negeri Selangor.

2. Untuk mengkaji faktor di antara konflik kerja dan konflik keluarga terhadap stres dalam kalangan pekerja kakitangan awam di Ibu Pejabat Polis Daerah Klang Selatan, Negeri Selangor.

3. Untuk mengkaji tahap konflik kerja, konflik keluarga dan stres dalam kalangan pekerja kakitangan awam di Ibu Pejabat Polis Daerah Klang Selatan, Negeri Selangor.

4. Untuk mengenal pasti perkaitan konflik kerja dan keluarga terhadap stres dalam kalangan pekerja kakitangan awam di Ibu Pejabat Polis Daerah Klang Selatan, Negeri Selangor.

Ho1 : Tiada perkaitan yang signifikan antara konflik kerja dengan stres dalam kalangan pekerja kakitangan awam di ibu Pejabat Polis Daerah Klang negeri Selangor.

Ho2 : Tiada perkaitan yang signifikan antara konflik keluarga dengan stres dalam kalangan pekerja kakitangan awam di ibu pejabat polis Daerah Klang negeri Selangor.

5. Untuk mengenal pasti perbezaan antara latar belakang demografi (umur, jantina, bangsa, pendapatan) dengan konflik kerja, konflik keluarga dan stres dalam kalangan pekerja kakitangan awam di Ibu Pejabat Polis Daerah Klang Selatan, Negeri Selangor.

Ho3 : Tiada perbezaan yang signifikan antara latar belakang demografi (umur) dengan konflik kerja, konflik keluarga dan stres dalam kalangan pekerja kakitangan awam di ibu Pejabat Polis Daerah Klang negeri Selangor.

Ho4 : Tidak terdapat perbezaan yang signifikan antara latar belakang demografi (jantina) dengan konflik kerja, konflik keluarga dan stres dalam kalangan pekerja kakitangan awam di Ibu Pejabat Polis Daerah Klang Selatan, Negeri Selangor.

Ho5 : Tidak terdapat perbezaan yang signifikan antara latar belakang demografi (bangsa) dengan konflik kerja, konflik keluarga dan stres dalam kalangan pekerja kakitangan awam di Ibu Pejabat Polis Daerah Klang Selatan, Negeri Selangor.

Ho6 : Tidak terdapat perbezaan yang signifikan antara latar belakang demografi (bilangan anak) dengan konflik kerja, konflik keluarga dan stres dalam kalangan pekerja kakitangan awam di Ibu Pejabat Polis Daerah Klang Selatan, Negeri Selangor.

Ho7 : Tidak terdapat perbezaan yang signifikan antara latar belakang demografi (pendapatan) dengan konflik kerja, konflik keluarga dan stres dalam kalangan pekerja kakitangan awam di Ibu Pejabat Polis Daerah Klang Selatan, Negeri Selangor.

\section{Analisis Data}

Analisis deskriptif

Analisis deskriptif

Analisis deskriptif (mean)

Ujian korelasi Pearson
Ujian t atau anova 
Reliability test (Cronbach's alpha) kajian telah dijalankan untuk menilai konsentasi setiap faktor. Cronbach's alpha digunakan untuk mengira skor varians yang konsisten dalam 1 set skor ujian dan ia biasanya antara 0-1. Nilai tinggi Cronbach's alpha menunjukkan konsistensi dalaman yang baik dari item dalam skala. Nilai Cronbach's alpha melebihi 0.60 sering kali digunapakai sebagai indeks kepercayaan sesuatu instrument (Mohd Majid, 1990; Pallant, 2001; Siti Rahayah, 2003). Dalam Jadual 7 semua faktor melebihi 0.8 .

Jadual 7: Keputusan Analisis Kebolehpercayaan Kajian

\begin{tabular}{ccc}
\hline Item & Bilangan Soalan & Cronbach's Alpha \\
\hline Konflik Kerja & 13 soalan & 0.862 \\
Konflik Keluarga & 13 soalan & 0.903 \\
Stres & 12 soalan & 0.855 \\
\hline
\end{tabular}

\section{Dapatan Kajian}

\subsection{Profil Responden Kajian}

Jadual 8 menunjukkan latar belakang demografi responden yang merangkumi 5 item iaitu jantina, bangsa, umur, bilangan anak dan pendapatan.

Jadual 8: Latar Belakang Sosial Demografi Responden (N=155)

\begin{tabular}{|c|c|c|}
\hline Item & Bilangan (n) & Peratus (\%) \\
\hline \multicolumn{3}{|l|}{ Jantina ( $\mathrm{N}=155)$} \\
\hline Lelaki & 102 & 65.8 \\
\hline Perempuan & 53 & 34.2 \\
\hline \multicolumn{3}{|l|}{ Bangsa( $N=155)$} \\
\hline Melayu & 138 & 89.0 \\
\hline India & 6 & 3.9 \\
\hline \multicolumn{3}{|l|}{ Bumiputera Sabah \& Sarawak : } \\
\hline Kadazan & 6 & 3.9 \\
\hline Murut & 2 & 1.3 \\
\hline Bajau & 3 & 1.9 \\
\hline \multicolumn{3}{|l|}{ Umur $(N=155)$} \\
\hline $20-29$ & 51 & 32.9 \\
\hline $30-39$ & 60 & 38.7 \\
\hline $40-49$ & 19 & 12.3 \\
\hline 50 dan ke atas & 25 & 16.1 \\
\hline \multicolumn{3}{|c|}{ Purata $=3.12, s . p=1.044, \min =2, \max =5, \operatorname{Var}=1.090$} \\
\hline \multicolumn{3}{|l|}{ Bilangan Anak (N=155) } \\
\hline Tiada Anak & 34 & 21.9 \\
\hline $1-2$ orang anak & 66 & 42.6 \\
\hline $3-4$ orang anak & 41 & 26.5 \\
\hline $5-6$ orang anak & 13 & 8.4 \\
\hline 7 - 8 orang anak & 1 & 0.6 \\
\hline \multicolumn{3}{|l|}{ Pendapatan $(\mathrm{N}=136)$} \\
\hline B40 (kurang daripada RM4,850) & 79 & 51.0 \\
\hline M40 (di antara RM4,851 - RM 10,970) & 75 & 48.4 \\
\hline T20 (RM 10,971 ke atas) & 1 & 0.6 \\
\hline
\end{tabular}

Secara keseluruhan, seramai 135 orang responden telah menjawab borang soal kaji selidik ini. 155 orang responden ini boleh dibahagikan kepada dua kumpulan jantina 
iaitu lelaki dan perempuan. Seramai 102 orang lelaki (65.8\%) dan 53 perempuan (34.2\%). Ini menunjukkan bilangan pekerja lelaki lebih tinggi berbanding bilangan pekerja perempuan yang menjawab borang soal kaji selidik ini.

Untuk item kedua iaitu pecahan berdasarkan bangsa, terdapat satu kumpulan bangsa yang dominan yang menjawab borang soal kaji selidik ini. Secara keseluruhan, bangsa ini dibahagikan kepada empat kumpulan bangsa iaitu Melayu, Cina, India dan Bumiputera Sabah dan Sarawak. Namun, setelah hasil dapatan kajian ini dikumpulkan, bangsa Cina tidak tersenarai di dalam Ibu Pejabat Polis Daerah Klang Selatan ini. Ini kerana di Ibu Pejabat Polis Daerah Klang Selatan hanya memiliki pekerja yang berbangsa Melayu, India dan Bumiputera Sabah dan Sarawak iaitu (Kadazan, Murut, Bajau). Latar belakang responden berbangsa Melayu merupakan yang paling ramai iaitu seramai 138 orang (89.0\%) kemudian diikuti dengan bangsa India iaitu seramai 6 orang (3.9\%) dan akhir sekali diikuti oleh Bumiputera Sabah \& Sarawak iaitu Kadazan seramai 6 orang (3.9\%), Murut seramai. 2 orang (1.3\%) dan Bajau seramai 3 orang (1.9\%).

Item yang ketiga pula pecahan umur yang merangkumi empat julat peringkat usia iaitu bermula dari 20-29 tahun, diikuti 30-39 tahun, 40-49 dan akhir sekali yang berusia 50 tahun dan ke atas. Hasil dapatan kajian mendapati seramai 51 orang (32.9\%) responden berada di usia yang berjulat 20-29 tahun. Manakala untuk julat usia 30-39 tahun, seramai 60 orang (38.7\%) responden. Seterusnya, julat bagi 40-49 tahun, seramai 19 orang $(12.3 \%)$ responden dan akhir sekali, seramai 25 orang responden $(16.1 \%)$ merupakan mereka yang berusia di julat 50 tahun dan ke atas.

Seterusnya untuk item keempat, pecahan responden berdasarkan bilangan anak. Pecahan kategori ini berdasarkan lima kumpulan iaitu pekerja yang tiada anak, pekerja yang memiliki 1-2 orang anak, pekerja yang memiliki 3-4 orang anak, pekerja yang memiliki 5-6 orang anak dan yang terakhir 7-8 orang anak. Hasil dapatan kajian yang dikumpulkan dari 155 orang pekerja kakitangan awam ini, pengkaji mendapati responden yang paling tinggi adalah responden yang telah berumah tangga yang memiliki 1-2 orang anak iaitu seramai 66 orang pekerja (42.6\%). Manakala diikuti dengan kedua tertinggi iaitu pekerja yang memiliki 3-4 orang anak iaitu seramai 41 orang pekerja $(26.5 \%)$. Untuk pekerja atau responden dalam kategori tiada anak pula adalah seramai 34 orang pekerja (21.9\%). Responden dalam kategori 5-6 orang anak adalaah seramai 13 orang (8.4\%). Akhir sekali, untuk kategori yang memiliki 7-8 orang anak adalah yang paling rendah iaitu hanya 1 orang pekerja $(0.6 \%)$.

Bagi item yang terakhir adalah item pendapatan. Ianya dibahagikan kepada 3 kumpulan iaitu B40, M40 dan T20. Untuk pekerja kakitangan awam yang memperoleh gaji paling tinggi adalah kumpulan B40 iaitu seramai 79 orang pekerja (51.0\%). Diikuti dengan kumpulan kedua tertinggi iaitu pekerja dari kakitangan awam yang memperoleh gaji untuk kumpulan M40 iaitu seramai 75 orang pekerja (48.4\%). Akhir sekali adalah pekerja yang terdiri dalam kumpulan T20 iaitu hanya 1 orang pekerja $(0.6 \%)$.

\subsection{Analisis Konflik Kerja, Konflik Keluarga dan Stres}

Jadual 9 menunjukkan penentuan tahap berdasarkan nilai min yang digunakan dalam kajian ini. Secara umumnya, terdapat tiga tahap utama iaitu tahap rendah (min 1-2.99), tahap sederhana (min 3.00) dan tahap tinggi (min 3.01-5.00). 
Jadual 9: Penentuan Tahap berdasarkan Nilai Min

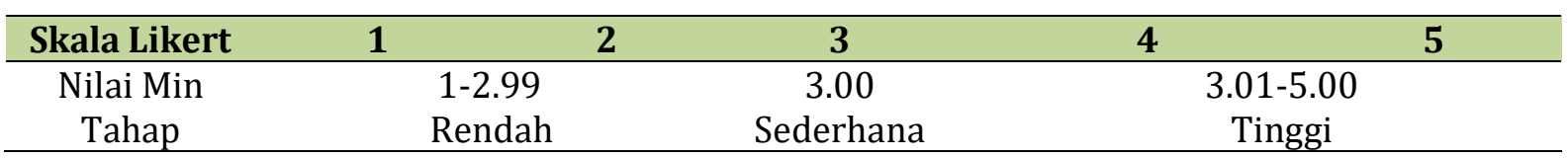

Jadual 10 menunjukkan nilai min bagi setiap konflik kerja, konflik keluarga dan stres berdasarkan jantina. Berdasarkan min tersebut, didapati bahawa konflik yang sangat mempengaruhi pekerja lelaki untuk memperoleh stres ialah ekoran daripada konflik keluarga. Konflik keluarga telah menunjukkan nilai min sebanyak 4.1750. Kedua, nilai min yang tertinggi pula adalah daripada konflik kerja iaitu sebanyak 3.9072. Yang terakhir, stres juga menunjukkan nilai min yang agak tinggi iaitu sebanyak 3.3701.

Jadual 10: Nilai Min mengikut Jantina bagi Konflik Kerja, Konflik Keluarga dan Stres

\begin{tabular}{ccc}
\hline Item & \multicolumn{2}{c}{ Nilai Min } \\
\cline { 2 - 3 } & \multicolumn{2}{c}{ Lelaki } \\
\hline Konflik Kerja & 3.9072 & 3.9303 \\
Konflik Keluarga & 4.1750 & 4.3803 \\
Stres & 3.3701 & 3.2123 \\
\hline
\end{tabular}

Bagi jantina perempuan pula konflik yang mempengaruhi mereka untuk memperoleh stres paling tertinggi adalah konflik keluarga iaitu menunjukkan nilai min sebanyak 4.3803, ini bermaksud nilai min jantina perempuan bagi konflik keluarga lebih tinggi berbanding lelaki. Diikuti dengan konflik kerja 3.9303 dan yang terakhir nilai min stres adalah sebanyak 3.213 .

Tahap konflik kerja, konflik keluarga dan stres dalam kalangan kakitangan awam di Ibu Pejabat Polis Daerah Klang Selatan berada pada tahap yang tinggi secara keseluruhannya. Berdasarkan kepada dapatan kajian, jumlah yang paling tinggi yang diperolehi adalah pada skor 4.2452 iaitu konflik keluarga dimana ianya sangat hampir dengan skor tertinggi iaitu 5. Oleh itu, penyelidik menyimpulkan bahawa konflik kerja, konflik keluarga dan stres bagi kakitangan awam di Ibu Pejabat ini masih berada pada tahap yang sangat memuaskan kerana skor minimum yang diperoleh masih berada pada skor melebihi 3. Dapatan kajian juga menunjukkan nilai purata bagi ketiga-tiga pemboleh ubah adalah sangat tinggi. Untuk dibandingkan min soalan dalam borang soal kaji selidik, untuk item yang mempunyai nilai min tertinggi bagi konflik kerja adalah item (rakan kerja saya sentiasa memberi pertolongan dan pendapat jika saya memerlukan) dengan nilai min 4.21, manakala bagi konflik keluarga item yang menunjukkan nilai min tertinggi adalah item (keluarga saya adalah keutamaan bagi saya) dan (saya sentiasa memberi kerjasama yang baik terhadap keluarga), keduanya menunjukkan nilai min sebanyak 4.51. Akhir sekali bagi stres item yang menunjukkan nilai min tertinggi adalah item (Dalam tempoh sebulan lalu, anda mampu mengawal perkara yang menyakitkan hati dalam hidup anda) dengan nilai min sebanyak 3.62.

Berdasarkan kepada borang soal selidik yang dikemukakan, penyelidik mendapati bahawa kakitangan di Ibu Pejabat ini mempunyai sikap yang produktif, kepimpinan, kualiti peribadi yang baik dan masih berada pada tahap yang terkawal. Majikan memainkan peranan penting dalam prestasi dan diri pekerja. Jika majikan berjaya memenuhi keperluan pekerja seperti pendapatan yang sesuai dengan kelayakan dan kemahiran mereka dan juga perlindungan dan keselamatan kerjaya terjamin, maka sudah semestinya tidak akan timbul sebarang konflik atau masalah terhadap diri 
pekerja sendiri. Dengan tindakan seperti ini, pekerja akan komited dan setia kepada majikan yang telah menunjukkan sikap bertolak ansur terhadap mereka. Pekerja akan sedar bahawa majikan peka akan kepentingan mereka dan ini akan membangkitkan motivasi intrinsik (dalaman) untuk bekerja dengan baik sejurus dapat melahirkan pekerja yang bebas dari sebarang tekanan. Tambahan pula, dapatan kajian menunjukkan responden mempunyai kualiti peribadi yang tinggi dari aspek jalinan hubungan dan kerjasama dengan rakan kerja, bekerja mengikut masa dan pekerja berpuas hati dengan tugasan yang diberikan. Majoriti responden berkebolehan untuk mewujudkan suasana kerjasama yang harmoni, mesra dan boleh menyesuaikan diri dalam semua keadaan. Mereka juga mempunyai daya kawal diri dari segi mental dan fizikal seperti mematuhi peraturan, menepati masa, bersemangat, berkeyakinan dan mereka mempunyai kesungguhan, ketekunan, dedikasi dan bertanggungjawab dalam melaksanakan tugas.

Bagi konflik keluarga pula, berdasarkan hasil dapatan kajian, majoriti pekerja kakitangan awam di Ibu Pejabat Daerah telah menunjukkan hubungan kebahagiaan terhadap keluarga dengan sangat baik. Mereka sering mengutamakan keluarga, memberi kerjasama, memberi sokongan, meluangkan masa, berkomunikasi dan mendengar pendapat antara satu sama lain. Hal ini selari dengan kajian yang telah dijalankan oleh Asmaningrum et al. (2014) dan Zaharah et al (2017) dimana dapatan hasil kajiannya mendapati bahawa sebuah keluarga mempunyai kesan yang positif terhadap menyelesaikan konflik atau kekangan yang dihadapi oleh ahli keluarga dengan hanya meluangkan masa dan menjadi pendengar sahaja. Mereka akan berasa selesa untuk berkomunikasi serta berbincang akan sesuatu hal tanpa ada rasa segan dan keluarga juga akan turut berkongsi perasaan yang dialami.

Begitu juga dengan stres, Keputusan soalan kaji selidik menunjukkan pekerja mempunyai perasaan diri yang baik. Menurut Robbins (2006) dan Darmawan (2018) mengatakan bahawa stres dapat ditakrifkan sebagai suatu keadaan dinamik dimana seseorang individu berhadapan dengan suatu peluang iaitu kekangan (constrain), tuntutan (demand) atau sumber daya yang berkaitan dengan apa juga kemahuannya dan hasilnya dipersepsikan sebagai suatu yang tidak pasti dan tidak penting. Menurut penelitian Rajak (2013) pula sumber utama dari tekanan setiap diri individu adalah dari konflik pekerjaan dan permintaan keluarga. Ini menunjukkan bahawa pekerja yang dapat mengurangkan stres sudah tentu akan hidup dalam keadaan tenang, bahagia dan harmoni. Tuntasnya, konflik kerja dan konflik keluarga yang positif dalam kalangan pekerja kakitangan awam di Ibu Pejabat Daerah ini secara tidak langsung mampu memberi kesan yang baik dan cekap sejurus dapat menghindarkan diri pekerja terhadap stres.

\subsection{Analisis Perkaitan antara Konflik Kerja dan Keluarga dengan Stres}

Jadual 11 menunjukkan interpretasi kekuatan hubungan angkubah berasaskan nilai korelasi, di mana nilai kolerasi (r) 0 bermaksud tidak ada kolerasi, nilai 0.00-0.25= kolerasi sangat lemah, 0.25-0.50 = kolerasi cukup, 0.50-0.75 = kolerasi kuat, 0.75-1.00 = kolerasi sangat kuat dan nilai 1.00 bermakna kolerasi sempurna. 
Jadual 11: Kekuatan Hubungan Korelasi

\begin{tabular}{cc}
\hline Nilai Kolerasi (r) & Kekuatan Hubungan \\
\hline 0 & Tidak ada kolerasi \\
$0.00-0.25$ & Kolerasi sangat lemah (dianggap tidak ada) \\
$0.25-0.50$ & Kolerasi cukup \\
$0.50-0.75$ & Kolerasi kuat \\
$0.75-1$ & Kolerasi sangat kuat \\
1 & Kolerasi sempurna \\
\hline
\end{tabular}

*korelasi negatif (-) interpretasi adalah sama

Jadual 12 menunjukkan hasil analisis kolerasi pearson dalam menentukan perkaitan antara konflik kerja dengan stres. Analisis kolerasi bagi perkaitan antara konflik kerja dengan stres dalam kalangan pekerja kakitangan awam di Ibu Pejabat Polis Daerah Klang Selatan telah menunjukkan hubungan signifikan yang sederhana iaitu cukup berdasarkan Jadual 12 dengan nilai $(r=0.280, p<0.01)$. Oleh itu, kajian ini menolak hipotesis $\mathrm{Ho}^{1}$, dimana terdapat hubungan yang signifikan antara konflik kerja dengan stres dalam kalangan pekerja kakitangan awam di Ibu Pejabat Polis Daerah Klang Selatan, Selangor.

Jadual 12: Analisis Perkaitan antara Konflik Kerja dengan Stres

\begin{tabular}{cccc}
\hline & Item & Konflik Kerja & Stres \\
\hline \multirow{3}{*}{ Konflik Kerja } & Korelasi Pearson & 1 & $.280^{* *}$ \\
& Sig. (2-tailed) & & .000 \\
& $\mathrm{~N}$ & 155 & 155 \\
\multirow{2}{*}{ Stres } & Korelasi Pearson & $.280^{* *}$ & 1 \\
& Sig. (2-tailed) & .000 & 155 \\
\hline
\end{tabular}

**. Correlation is significant at the 0.01 level (2-tailed)

Jadual 13 menunjukkan hasil analisis kolerasi pearson dalam menentukan perkaitan antara konflik keluarga dengan stres. Analisis kolerasi bagi perkaitan antara konflik keluarga dengan stres dalam kalangan pekerja kakitangan awam di Ibu Pejabat Polis Daerah Klang Selatan telah menunjukkan hubungan sangat lemah dan dianggap tiada korelasi berdasarkan Jadual 11 dengan nilai $(r=0.231, p<0.01)$. Oleh itu, kajian ini menolak hipotesis $\mathrm{Ho}^{2}$, dimana terdapat hubungan yang signifikan antara konflik keluarga dengan stres dalam kalangan pekerja kakitangan awam di Ibu Pejabat Polis Daerah Klang Selatan, Selangor.

Jadual 13: Analisis Perkaitan antara Konflik Keluarga dengan Stres

\begin{tabular}{cccc}
\hline & Item & Konflik Keluarga & Stres \\
\hline \multirow{3}{*}{ Konflik Keluarga } & Korelasi Pearson & 1 & $.231^{* *}$ \\
& Sig. (2-tailed) & & .004 \\
& $\mathrm{~N}$ & 155 & 155 \\
\multirow{2}{*}{ Stres } & Korelasi Pearson & $.231^{* *}$ & 1 \\
& Sig. (2-tailed) & .004 & 155 \\
\hline
\end{tabular}

**. Correlation is significant at the 0.01 level (2-tailed) 
Berdasarkan kepada dapatan kajian yang diperoleh, kajian ini telah menolak dua daripada hipotesis null yang dibina iaitu Ho1 yang mengkaji perkaitan antara konflik kerja dengan stres dan Ho2 yang mengkaji hubungan antara konflik keluarga dengan stres. Ini kerana ianya mempunyai hubungan yang signifikan. Manakala keputusan nilai korelasi Pearson yang menghubungkaitkan antara konflik kerja dan konflik keluarga dengan stres dalam kalangan kakitangan awam di ibu Pejabat Polis Daerah ini mendapati hubungan korelasi yang cukup dengan nilai $r=0.280^{* *}$ pada aras $\mathrm{p}<0.05$ dan $\mathrm{p}<0.01$ (bagi konflik kerja dengan stres). Seterusnya, nilai $\mathrm{r}=0.231^{* *}$ pada aras $\mathrm{p}<0.05$ dan $\mathrm{p}<0.01$ (bagi konflik keluarga dengan stres). Oleh yang demikian, kajian ini menolak hipotesis alternatif (Ho1 dan Ho2) dimana terdapat hubungan yang signifikan antara konflik kerja dan konflik keluarga dengan stres dalam kalangan kakitangan awam.

Pengaruh konflik kerja dan keluarga terhadap stres mempengaruhi prestasi diri seseorang pekerja kerana apabila mereka mengalami masalah serta konflik sama ada dari faktor pekerjaan atau keluarga, mereka akan berasa tertekan untuk memberi perkhidmatan yang berkualiti disebabkan tidak bersemangat dan tiada kesungguhan hasil dari impak masalah luar yang datang, yang mengganggu pemikiran serta komitmen diri. Kajian ini disokong oleh Hammer et al. (2004), Bazana dan Dodd (2013) serta Indriyani (2009) dalam penelitiannya mengatakan "semakin tinggi konflik kerja dan konflik keluarga, maka semakin tinggi pula stres yang dihadapi oleh pekerja. Seterusnya berdasarkan kajian Agustina dan Sudibya (2018). pula, yang menunjukkan terdapat hubungan yang signifikan antara konflik kerja dan konflik keluarga terhadap stres dengan nilai $\mathrm{p}<0.05$. Selain itu, kajian membuktikan bahawa beberapa sumber tekanan di tempat kerja merangkumi beban kerja yang berlebihan, pengawasan yang tidak mencukupi, kekaburan peranan dan kurangnya pengiktirafan. Tekanan kerja akan memberi impak ketara dari segi produktiviti rendah, pekerja yang sakit, dan pengurusan masa yang tidak teratur. Pernyataan ini menunjukkan bahawa tekanan yang berlebihan membawa kepada perubahan tingkah laku, secara psikologi dan emosi pekerja sehingga boleh mengganggu prestasi merangkumi kualiti dan kuantiti kerja yang kurang memuaskan.

Begitu juga dengan konflik keluarga, menurut Adkins dan Premeaux (2012) ada jangkaan yang berkaitan dengan peranan tertentu (pekerjaan) dan harapan itu menyebabkan individu gagal memenuhi tanggungjawab peranan lain (keluarga), ini menyebabkan prestasi peranan yang lemah dan membawa kepada konflik keluarga sejurus mengundang stres. Konflik kerja dan keluarga adalah konflik antara peranan yang berlaku kepada individu akibatnya ketidakupayaan untuk membahagikan dua peranan tersebut (Netemeyer et al., 1996). Saat ini, semakin ramai pekerja yang merasa sukar untuk mengimbangkan tuntutan antara kerja dan tanggungjawab dalam keluarga, sehingga mendorongnya konflik antara pekerjaan dan kehidupan keluarga (Alazzam et al., 2017). Daripada definisi dan kajian tersebut dapat disimpulkan bahawa konflik kerja dan keluarga merupakan perkara yang perlu diutamakan untuk mengelakkan dari berlakunya masalah dan bebanan yang boleh membawa kepada stres. Apabila hal kerja dan hal keluarga dapat diimbangkan serta dibahagikan mengikut kesesuaian dan keutamaan yang betul, maka tekanan atau stres yang diperolehi oleh pekerja dapat dikurangkan serta dihapuskan dengan baik. 


\subsection{Analisis Perbezaan antara Angkubah Jantina dengan Konflik Kerja, Konflik Keluarga dan Stres}

Jadual 14 dibawah menunjukkan dapatan hasil analisis kajian menggunakan ujian $T$ (TTest) untuk melihat adakah terdapat perbezaan yang signifikan antara latarbelakang jantina dengan konflik kerja, koflik keluarga dan stres. Berdasarkan Jadual 14 tiada perbezaan yang signifikan angkubah jantina dengan konflik kerja, konflik keluarga dan stres. Analisis perbezaan $\mathrm{Ho}^{3 \mathrm{i}}$ iaitu latar belakang jantina dengan konflik kerja menunjukkan terdapat perbezaan yang signifikan dengan nilai $t=-0.259, \mathrm{p}=0.038<$ 0.05. Seterusnya perbezaan $\mathrm{Ho}^{3 \mathrm{ii}}$ iaitu latar belakang jantina dengan konflik keluarga menunjukkan tiada perbezaan yang signifikan dengan nilai $t=-1.918, p=0.451>0.05$. Kemudian akhir sekali, Ho ${ }^{3 i i}$ iaitu latar belakang jantina dengan stres menunjukkan tiada perbezaan yang signifikan dengan nilai $t=1.208, p=0.984>0.05$. Oleh yang demikian, kajian ini menerima hipotesis null $\mathrm{Ho}^{3 \mathrm{ii}}$ dan $\mathrm{Ho}^{3 \mathrm{iii}}$ kerana jantina tidak mempengaruhi konflik keluarga dan stres. Namun, menolak hipotesis $\mathrm{Ho}^{3 i}$ kerana terdapat perbezaan yang signifikan antara latar belakang jantina dengan konflik kerja.

Jadual 14: Analisis Perbezaan di antara Angkubah Jantina dengan Konflik kerja,

Konflik Keluarga dan Stres

\begin{tabular}{|c|c|c|c|c|c|c|c|c|c|c|}
\hline \multirow[t]{3}{*}{ Item } & & \multicolumn{2}{|c|}{$\begin{array}{l}\text { Levene's } \\
\text { Test for } \\
\text { Equality of } \\
\text { Variances }\end{array}$} & \multicolumn{7}{|c|}{ t-test for Equality of Means } \\
\hline & & \multirow[t]{2}{*}{$\mathbf{F}$} & \multirow[t]{2}{*}{ Sig. } & \multirow[t]{2}{*}{$\mathbf{t}$} & \multirow[t]{2}{*}{ df } & \multirow[t]{2}{*}{$\begin{array}{l}\text { Sig. (2- } \\
\text { tailed) }\end{array}$} & \multirow[t]{2}{*}{$\begin{array}{l}\text { Mean } \\
\text { Diff. }\end{array}$} & \multirow[t]{2}{*}{$\begin{array}{l}\text { Std. Error } \\
\text { Difference }\end{array}$} & \multicolumn{2}{|c|}{$\begin{array}{l}95 \% \text { Confidence } \\
\text { Interval of the } \\
\text { Difference }\end{array}$} \\
\hline & & & & & & & & & Lower & Upper \\
\hline \multirow{6}{*}{$\begin{array}{l}\text { Konflik } \\
\text { Kerja }\end{array}$} & Equal & 4.38 & .03 & -.25 & 153 & .79 & - & .0892 & -.1993 & .15313 \\
\hline & variances & 1 & 8 & & & & .0230 & & & \\
\hline & $\begin{array}{l}\text { assumea } \\
\text { /Equal }\end{array}$ & & & -.24 & 91.48 & .80 & - & .0939 & -.2097 & .1635 \\
\hline & variances & & & & & & .0230 & & & \\
\hline & not & & & & & & & & & \\
\hline & assumed & & & & & & & & & \\
\hline \multirow{6}{*}{$\begin{array}{l}\text { Konflik } \\
\text { Keluarga }\end{array}$} & Equal & .572 & .45 & -1.91 & 153 & .05 & - & .1070 & .4167 & .0061 \\
\hline & variances & & 1 & & & & .2053 & & & \\
\hline & $\begin{array}{l}\text { assumed } \\
\text { Equal }\end{array}$ & & & -1.97 & 114.5 & .05 & - & .1038 & .4111 & .0005 \\
\hline & variances & & & & 2 & & .2053 & & & \\
\hline & not & & & & & & & & & \\
\hline & assumed & & & & & & & & & \\
\hline \multirow[t]{6}{*}{ Stres } & Equal & .000 & .98 & 1.20 & 153 & .22 & .1578 & .1307 & -.1003 & .4160 \\
\hline & variances & & 4 & 8 & & & & & & \\
\hline & $\begin{array}{l}\text { assumed } \\
\text { / Equal }\end{array}$ & & & 1.17 & 98.02 & .24 & .1578 & .1342 & -.1085 & .4241 \\
\hline & variances & & & 6 & & & & & & \\
\hline & not & & & & & & & & & \\
\hline & assumed & & & & & & & & & \\
\hline
\end{tabular}

Mengikut min skor borang soal kaji selidik pada konflik kerja, perempuan menunjukkan nilai min yang lebih tinggi berbanding lelaki iaitu sebanyak 3.93 nilai min pekerja perempuan dan 3.90 nilai min pekerja lelaki. Dapatan ini disokong oleh kajian Thi (1998), yang turut mendapati pengurus dan eksekutif perempuan mengalami konflik kerja yang lebih tinggi berbanding dengan pengurus dan eksekutif lelaki. Kajian juga 
menunjukkan walaupun terdapat persamaan punca konflik kerja di antara pekerja lelaki dan perempuan, namun terdapat juga perbezaannya mengikut soalan kaji selidik. Sebagai contoh pekerja lelaki menganggap keadaan seperti berani mengambil risiko, kesan-kesan dari kesilapan yang dilakukan, pertindihan tugas dan perkembangan kerjaya sebagai punca tekanan. Manakala bagi pekerja wanita pula keadaan seperti peluang untuk perkembangan diri, kadar gaji, perlu berfikir idea-idea baru dan terpaksa bekerja lebih masa merupakan punca tekanan yang tinggi.

\subsection{Analisis Perbezaan antara Angkubah Umur dengan Konflik Kerja, Konflik Keluarga dan Stres}

Jadual 15 menunjukkan analisis perbezaan antara umur dengan konflik kerja, konflik keluarga dan stres. Analisis perbezaan antara umur dengan konflik kerja menunjukkan nilai $\mathrm{F}(3,151)=.574, \mathrm{p}=.633>0.05$, manakala umur dengan konflik keluarga adalah $\mathrm{F}$ $(3,151)=1.160, p=.327>0.05$, dan umur dengan stres pula adalah $F(3,151)=2.490, p$ $=.063>0.05$. Oleh yang demikian, analisa kajian ini didapati bahawa tiada perbezaan yang signifikan antara latar belakang umur dengan konflik kerja, konflik keluarga dan stres.

Jadual 15: Analisis Perbezaan antara Angkubah Umur dengan Konflik Kerja, Konflik Keluarga dan Stres

\begin{tabular}{lllllll}
\hline Item & & $\begin{array}{l}\text { Sum of } \\
\text { Squares }\end{array}$ & df & $\begin{array}{l}\text { Mean } \\
\text { Square }\end{array}$ & F & Sig. \\
\hline Konflik Kerja & Between Groups & $\mathbf{. 4 7 9}$ & $\mathbf{3}$ & $\mathbf{. 1 6 0}$ & $\mathbf{. 5 7 4}$ & $\mathbf{. 6 3 3}$ \\
& Within Groups & 41.997 & 151 & .278 & & \\
Konflik Keluarga & Total & 42.475 & 154 & & & \\
& Between Groups & 1.411 & 3 & .470 & 1.160 & .327 \\
& Within Groups & 61.214 & 151 & .405 & & \\
Stres & Total & 62.625 & 154 & & & \\
& Between Groups & 4.337 & 3 & 1.446 & 2.490 & .063 \\
& Within Groups & 87.686 & 151 & .581 & & \\
& Total & 92.024 & 154 & & & \\
\hline
\end{tabular}

\subsection{Analisis Perbezaan Angkubah Bangsa dengan Konflik Kerja, Konflik Keluarga dan Stres}

Jadual 16 menunjukkan analisis perbezaan antara bangsa dengan konflik kerja, konflik keluarga dan stres. Analisis perbezaan antara bangsa dengan konflik kerja menunjukkan nilai $\mathrm{F}(4,150)=1.944, \mathrm{p}=.106>0.05$, manakala bagi bangsa dengan konflik keluarga adalah $\mathrm{F}(4,150)=.877, \mathrm{p}=.480>0.05$, dan bangsa dengan stres pula adalah $\mathrm{F}(4,150)=$ $.053, \mathrm{p}=.995>0.05$. Oleh yang demikian, analisa kajian ini didapati bahawa tiada perbezaan yang signifikan di antara latar belakang bangsa dengan konflik kerja, konflik keluarga dan stres. 
Jadual 16: Analisis Perbezaan antara Angkubah Bangsa dengan Konflik Kerja, Konflik Keluarga dan Stres

\begin{tabular}{|c|c|c|c|c|c|c|}
\hline Item & & $\begin{array}{l}\text { Sum of } \\
\text { Squares }\end{array}$ & df & $\begin{array}{l}\text { Mean } \\
\text { Square }\end{array}$ & $\mathbf{F}$ & Sig. \\
\hline \multirow[t]{3}{*}{ Konflik Kerja } & Between Groups & 2.093 & 4 & .523 & 1.944 & .106 \\
\hline & Within Groups & 40.382 & 150 & .269 & & \\
\hline & Total & 42.475 & 154 & & & \\
\hline \multirow[t]{3}{*}{ Konflik Keluarga } & Between Groups & 1.430 & 4 & .358 & .877 & .480 \\
\hline & Within Groups & 61.194 & 150 & .408 & & \\
\hline & Total & 62.625 & 154 & & & \\
\hline \multirow[t]{3}{*}{ Stres } & Between Groups & .129 & 4 & .032 & .053 & .995 \\
\hline & Within Groups & 91.895 & 150 & .613 & & \\
\hline & Total & 92.024 & 154 & & & \\
\hline
\end{tabular}

\subsection{Analisis Perbezaan Angkubah Bilangan Anak dengan Konflik Kerja, Konflik Keluarga dan Stres}

Jadual 17 menunjukkan analisis perbezaan antara latar belakang bilangan anak dengan konflik kerja, konflik keluarga dan stres. Analisis perbezaan antara bilangan anak dengan konflik kerja menunjukkan nilai $\mathrm{F}(4,150)=1.341, \mathrm{p}=.258>0.05$, manakala bagi bilangan anak dengan konflik keluarga adalah $\mathrm{F}(4,150)=2.426, \mathrm{p}=.050<0.05$, dan bilangan anak dengan stres pula adalah $\mathrm{F}(4,150)=2.278, \mathrm{p}=.065>0.05$. Oleh yang demikian, analisa kajian ini didapati bahawa tiada perbezaan yang signifikan antara latar belakang bilangan anak dengan konflik kerja dan stres kecuali bilangan anak dengan konflik keluarga kerana mempunyai perbezaan signifikan.

Jadual 17: Analisis Perbezaan antara Angkubah Bilangan Anak dengan Konflik Kerja, Konflik Keluarga dan Stres

\begin{tabular}{lllllll}
\hline Item & & $\begin{array}{l}\text { Sum of } \\
\text { Squares }\end{array}$ & df & $\begin{array}{l}\text { Mean } \\
\text { Square }\end{array}$ & F & Sig. \\
\hline Konflik Kerja & Between Groups & 1.466 & 4 & .367 & 1.341 & .258 \\
& Within Groups & 41.009 & 150 & .273 & & \\
\multirow{5}{*}{ Konflik Keluarga } & Total & 42.475 & 154 & & & \\
& Between Groups & 3.805 & 4 & .951 & 2.426 & .050 \\
& Within Groups & 58.819 & 150 & .392 & & \\
Stres & Total & 62.625 & 154 & & & \\
& Between Groups & 5.269 & 4 & 1.317 & 2.278 & .064 \\
& Within Groups & 86.755 & 150 & .578 & & \\
& Total & 92.024 & 154 & & & \\
\hline
\end{tabular}

Oleh itu, dapat disimpulkan bahawa bilangan anak memainkan peranan penting dalam konflik keluarga kerana jika pekerja tidak dapat membahagikan dan menguruskan hal anak dengan baik, maka konflik atau masalah terhadap pekerja akan timbul. Dengan melihat kepada nilai skor min untuk data analisis kajian, skor yang paling tinggi adalah 4.3964 iaitu pekerja yang mempunyai bilangan anak dalam lingkungan 5 hingga 6 orang. Daripada perspektif keluarga, kajian lepas mendapati pasangan yang berkahwin mengalami konflik yang tinggi berbanding yang masih bujang (Grzywacz \& Butler, 2005). Manakala pasangan yang mempunyai anak juga dilaporkan mengalami konflik yang tinggi berbanding dengan pasangan yang tidak mempunyai anak. Selain itu, kajian oleh Hashim (2005) dalam kalangan famili kelas pertengahan di Shah Alam, mendapati purata bilangan anak yang paling sesuai untuk sebuah keluarga adalah empat orang. 
Maka ini dapat dilihat bahawa bilangan anak mampu memberi impak yang besar kepada konflik keluarga.

\subsection{Analisis Perbezaan Angkubah Pendapatan dengan Konflik Kerja, Konflik Keluarga dan Stres}

Jadual 18 di bawah menunjukkan analisis perbezaan antara latar belakang pendapatan dengan konflik kerja, konflik keluarga dan stres. Analisis perbezaan antara pendapatan dengan konflik kerja menunjukkan nilai $\mathrm{F}(2,152)=4.015, \mathrm{p}=.020<0.05$, manakala pendapatan dengan konflik keluarga adalah $\mathrm{F}(2,152)=2.411, \mathrm{p}=.093>0.05$, dan pendapatan dengan stres pula adalah $F(2,152)=8.576, p=.000<0.05$. Oleh yang demikian, analisa kajian ini didapati bahawa tiada perbezaan yang signifikan antara latar belakang pendapatan dengan konflik keluarga kecuali pendapatan dengan konflik kerja dan stres kerana mempunyai perbezaan signifikan.

Jadual 18: Analisis Perbezaan antara Angkubah Pendapatan dengan Konflik Kerja, Konflik Keluarga dan Stres

\begin{tabular}{lllllll}
\hline Item & & $\begin{array}{l}\text { Sum of } \\
\text { Squares }\end{array}$ & df & $\begin{array}{l}\text { Mean } \\
\text { Square }\end{array}$ & F & Sig. \\
\hline Konflik Kerja & Between Groups & 2.131 & 2 & 1.066 & 4.015 & .020 \\
& Within Groups & 40.344 & 152 & .265 & & \\
Konflik Keluarga & Total & 42.475 & 154 & & & \\
& Between Groups & 1.925 & 2 & .963 & 2.411 & .093 \\
& Within Groups & 60.699 & 152 & .399 & & \\
& Total & 62.625 & 154 & & & \\
& Between Groups & 9.332 & 2 & 4.666 & 8.576 & .000 \\
& Within Groups & 82.692 & 152 & .544 & & \\
& Total & 92.024 & 154 & & & \\
\hline
\end{tabular}

Selain itu, hasil kajian juga menunjukkan perbezaan yang signifikan antara pendapatan terhadap konflik kerja dengan nilai $F(2,152)=4.015, p=.020<0.05$ dan antara pendapatan terhadap stres dengan nilai $F(2,152)=8.576, p=.000<0.05$. Bagi konflik kerja ini menunjukkan golongan M40 iaitu yang bergaji (di antara RM4,851 - RM 10,970) yang menunjukkan ada perbezaan yang signifikan. Begitu juga dengan stres golongan M40 iaitu yang bergaji (di antara RM4,851 - RM 10,970) menunjukkan ada perbezaan yang signifikan. Ini menunjukkan bahawa faktor pendapatan yang diperoleh menjadi faktor kepada tekanan yang dihadapi oleh anggota polis. Anggota polis yang berpendapatan tinggi lazimnya adalah daripada kalangan mereka yang berjawatan besar dan penting dalam organisasi. Semakin tinggi jawatan yang disandang, semakin tinggilah tekanan dan konflik yang akan mereka tempuhi. Kenyataan ini turut disokong oleh kajian Masilamani et al. (2013) serta Nursyazlin dan Noraini (2017) yang mendapati bahawa anggota polis yang berpangkat Inspektor lebih mengalami stres berbanding anggota polis yang lain kerana faktor tanggungjawabnya yang besar dalam sudut penyiasatan kes, tugas khas, jenayah komersil, operasi khas (seperti membendung jenayah serta keganasan) dan jenayah narkotik.

\subsection{Pengaruh Konflik Kerja dan Konflik Keluarga Terhadap Stres}

Berdasarkan Jadual 19, nilai-p bagi Anova adalah 0.001 yang mana kurang daripada 0.05. Ini bermaksud model ini mempunyai signifikan yang sah. Memandangkan model 
ini mempunyai signifikan yang sah maka model ini boleh digunakan untuk tujuan interpretasi selanjutnya.

Jadual 19: Model Regresi

\begin{tabular}{llllll}
\hline & Sum of Squares & df & Min Square & F & Sig. \\
\hline Regression & $\mathbf{8 . 1 2 3}$ & 2 & 4.062 & 7.358 & .001 b \\
Residual & $\mathbf{8 3 . 9 0 0}$ & 152 & .552 & & \\
Total & $\mathbf{9 2 . 0 2 4}$ & 154 & & & \\
\hline
\end{tabular}

Jadual 20 menunjukkan model kawalan konflik kerja, konflik keluarga dan stres. Nilai $R$ squared menunjukkan bagaimana model tersebut boleh menerangkan konflik kerja dan keluarga dalam mempengaruhi stres bagi kalangan pekerja kakitangan awam di Ibu Pejabat Polis Daerah Klang Selatan. Nilai R-squared untuk model ini adalah 0.088, bermaksud hampir 8.8\% menunjukkan pemboleh ubah tidak bersandar mempengaruhi pemboleh ubah bersandar. Baki 91.2\% hanya boleh dijelaskan oleh pemboleh ubah tidak bersandar yang lain.

Jadual 20: Model Kawalan Konflik Kerja dan Konflik Keluarga dan Stres

\begin{tabular}{lllllll}
\hline Model & $R$ & R Square & $\begin{array}{l}\text { Adjusted } R \\
\text { Square }\end{array}$ & Df & $F$ & Sig. \\
\hline 1 & $.297^{a}$ & .088 & .076 & 2 (Regression) & 7.358 & $.001^{\mathrm{b}}$ \\
\hline
\end{tabular}

Berdasarkan Jadual 21 di bawah, terdapat dua pemboleh ubah tidak bersandar yang menyumbang kepada stres dalam kalangan pekerja kakitangan awam di Ibu Pejabat Polis Daerah Klang Selatan iaitu konflik kerja dan konflik keluarga. Konflik kerja dengan nilai $(\mathrm{p}=0.017)$ menunjukkan nilai signifikan yang tinggi berbanding konflik keluarga ( $\mathrm{p}=0.205$ ), dengan nilai R2 0.088. Maka, hasil ini menunjukkan bahawa konflik kerja faktor dominan yang kuat menyumbang terhadap stres berbanding konflik keluarga.

Jadual 21: Regresi berganda faktor dominan antara konflik kerja dan konflik keluarga terhadap stres

\begin{tabular}{llllll}
\hline Faktor & & $\begin{array}{l}\text { Unstandardized } \\
\text { Beta }(B)\end{array}$ & $\begin{array}{l}\text { Standardized } \\
\text { Beta }(B)\end{array}$ & $t$ & $p$ \\
\hline Konflik Kerja & & .323 & .219 & 2.408 & .017 \\
Konflik & & .140 & .116 & 1.273 & .205 \\
Keluarga & 7.358 & & & & \\
$F$ & 2 & & & & \\
$d f$ & $0.297 \mathrm{a}$ & & & & \\
$\boldsymbol{R}$ & $\mathbf{0 . 0 8 8}$ & & & \\
$\boldsymbol{R}^{2}$ & $\mathbf{0 . 0 7 6}$ & & & \\
Adjusted $\boldsymbol{R}^{2}$ & & & & \\
\hline
\end{tabular}

\section{Kesimpulan}

Kajian ini telah mengesahkan bahawa konflik kerja dan konflik keluarga mampu mempengaruhi stres dalam kalangan responden bertepatan dengan keputusan hubungan yang signifikan antara konflik kerja dan konflik keluarga dengan stres. Majoriti kakitangan dalam Ibu Pejabat Polis Daerah Klang Selatan tidak menunjukkan 
stres atau tekanan pada tahap yang tinggi sehingga boleh mengganggu kesihatan serta prestasi kerja. Selain itu, dapatan kajian juga mendapati perbezaan yang signifikan antara konflik kerja dan stres terhadap pendapatan. Manakala, untuk konflik keluarga menunjukkan hubungan signifikan terhadap jumlah bilangan anak. Pada akhir kajian ini juga disertakan beberapa cadangan sebagai panduan dan tindakan yang sewajarnya yang boleh diambil oleh pihak-pihak tertentu.

\section{Penghargaan (Acknowledgement)}

Terima kasih kepada Ibu Pejabat Polis Daerah Klang Selatan, Negeri Selangor yang telah memberi kerjasama dalam menjayakan kajian ini .

\section{Kewangan (Funding)}

Tidak menerima sebarang tajaan atau bantuan kewangan.

\section{Konflik Kepentingan (Conflict of Interests)}

Para penulis tidak mempunyai konflik kepentingan dalam menjalankan kajian dan penerbitan ini.

\section{Rujukan}

Adkins, C. L., \& Premeaux, S. F. (2012). Spending Time: The Impact of Hours Worked on Work-Family Conflict. J. Vocational Behav, 80 (2), 380-389. doi:10.1016/j.jvb.2011.09.003

Agustina, R., \& Sudibya, I. (2018). Pengaruh Work Family Conflict Terhadap Stres Kerja Dan Kinerja Wanita Perawat Di Rumah Sakit Umum Daerah Praya Lombok. EJurnal Ekonomi Dan Bisnis Universitas Udayana, 775-808. doi:10.24843/EEB.2018.v07.i03.p06

Alazzam, M., Abualrub, R. F., \& Nazzal, A. H. (2017). The relationship between workfamily conflict (WFC) and job satisfaction among Jordanian hospital nurses. Nursing Forum 52(4).

Anafarta, N. (2011). The Relationship between workfamily conflict and job satisfaction: a structural equation modeling (SEM) approach. Int J Bus. Manage, 6(4), 168-77.

Apperson, M., Schmidt. H., Moore. S., \& Grunberg. L. \& Greenberg E. (2002). Women Managers and the Experience of Work-Family Conflict. American Journal of Undergraduate Research, 1(3).

Asfahyadin, L. A., Nofal, N., Muh, T., Gusli, T. S., Rosmawaty., Kartini., \& Mirad. (2017). The Influence of Work Family Conflict and Work Stress on Employee Performance. International Journal of Management and Applied Science, 3(2), 1-6.

Asmaningrum, N., Wijaya, D., \& Wijaya, C. A. (2014). Dukungan Sosial Keluarga Sebagai Upaya Pencegahan Stres Pada Lansia Dengan Andropause Di Desa Gebang Wilayah Kerja Puskesmas Patrang Kabupaten Jember. Jurnal IKESMA, 10(1), 78-86.

Astro Awani (2019). Penjawat awam berisiko tinggi alamai tekanan kerja. Berita Awani. https://www.astroawani.com/berita-malaysia/penjawat-awam-berisiko-tinggialami-tekanan-kerja-209280

Bazana, S. \& Dodd, N. (2013). Conscientiousness, Work Family Conflict and Stress amongst Police Officers in Alice, South Africa. Journal of Psychology, 4(4), 1-8. 
Boyar, S. L., Maetz, C. P., Mosley, D. C., \& Carr, J. C. (2008). The Impact of Work/Family Demand On Work-Family Conflict. Journal of Managerial Psychology, 23(3), 215235.

Brinson, S. L., \& Benoit, W. L. (1999). The tarnished star: Restoring Texaco's damaged public image. Communication Quarterly, 12, 483-510.

Cohen, S. (1994). Perceived Stress Scale. Mind Garden.

Cooper, C. L., \& Cartwright, S. (1994). Healthy Mind; Healthy Organization- A Proactive Approach to Occupational Stress. Human Relations, 47(4), 455-471. https://doi.org/10.1177/001872679404700405

Darmawan, D. (2019). Peranan Motivasi Dan Kompetensi: Analisis Kinerja Pegawai Pemerintahan Daerah Kabupaten Paser. At-Tadbir: Jurnal Ilmiah, 3(2), 122-131.

Fontana, D. (1989). Managing stress. British Psychological Society; Taylor \& Frances/Routledge.

Ganing, C. F., Hassan, M. M., \& Wan Hamzah, W. N. N. (2020). Faktor-faktor yang Mempengaruhi Tekanan Kerja di kalangan Kakitangan Hospital Kerajaan. Malaysian Journal of Social Sciences and Humanities (MJSSH), 5(10), 151-177. https://doi.org/https://doi.org/10.47405/mjssh.v5i10.522

Greenhaus, J. H. \& Nicholas, J. B. (1985). Sources of Conflict Between Work and Family Roles1. Academy of Management Review, 10(1), 76-88.

Grzywacz, J. G. \& Butler, A. (2005). The Impact of Job Characteristics on Work-to-Family Facilitation: Testing a Theory and Distinguishing a Construct. Journal of Occupational Health Psychology, 10(2), 97-109.

Grzywacz, J. G., Almeida, D. M., \& McDonald, D. A. (2002). Work-family spillover and daily reports of work and family stress in the adult labor force. Fam. Relat, 51, 2836. doi: 10.1111/j.1741-3729.2002.00028.x

Hammer, L. B., Huang Yueng-Hsiang, Neal, M. B., \& Perrin, N. (2004). The Relationship Between Work-To-Family Conflict and Family-To-Work Conflict: A Longitudinal Study. Journal of Family and Economic Issues, 25(1),79-100.

Handoko, T. H. (2008). Manajemen Personalia Dan Sumber Daya Manusia. Edisi XIV. Yogyakarta, BPFE,

Harussani, H. Z. (2004). Pengurusan Stress, Satu Tinjauan dari Perspektif Islam. Kertas Kerja yang dibentangkan dalam Bengkel Pengurusan Stress Menurut Perspektif Islam, Institut Pembangunan Pengurusan Johor dan IKIM, pada 27-28 Julai 2004.

Hashim, I. M. (2005). Exploring the linkages between children's independent migration and education: Evidence from Ghana, DRC on migration, globalization and poverty. Brighton: University of Sussex.

Hyun, J. C. \& Young, T. K (2012). Work-family conflict, work-family facilitation, and job outcomes in the Korean hotel industry. International Journal of Contemporary Hospitality Management, 24(7), 1011-1028

Imani, N. K., Werdani, R. \& Pinem, R. (2018). Analisis Pengaruh Work Family Conflict dan Beban Kerja Terhadap Stres Kerja Dalam Mempengaruhi Turnover Intention (Studi Pada Karyawan PT. Bank Negara Indonesia (Persero), Tbk Wilayah Semarang). Jurnal Administrasi Bisnis, 7(2), 95-102.

Indriyani, A. (2009). Pengaruh Konflik Peran Ganda Dan Stres Kerja Terhadap KinerjaWanita perawat Rumah Sakit. Thesis. Program Studi Magister Manajemen Program Pascasarjana Universitas Diponegoro Semarang.

Junike Sorongan, Lery Fransil S., \& Harvani Boky (2018). Hubungan Antara Stres Kerja Dan Upah Dengan Produktivitas Kerja Pada Pegawai Di Dinas Kesehatan Kota Manado. Jurnal KESMAS, 7(5).

Kahn, R. L. \& Quinn, R. P. (1970). Role stress: A framework for analysis. In a mclean (ed). Mental Health and Work Organization. Chiocago: Rand McNally. 
Karabaya, M. E., Bulent, A., \& Meralelci. (2013). Effects of Family-Work Conflict, Locus of Control, Self Confidence and Extraversion Personality on Employee Work Stress. Procedia -Social and Behavioral Science, 235, 269 -280

Kazmi, S. S. A., Muhammad, H., Mehboob, U., Syeikh, R. M., \&. Muhammad, A. K. (2017). Impact Of Job Stress on Work Family Conflict: A Case Study of Bankers Of Private Sector Banks In Peshawar, Pakistan. City University Research Journal, 195-205

Keliat Budi Ana (1999). Proses Keperawatan Kesehatan Jiwa, Edisi 1, EGC, Jakarata.

Khashimah Ismail (2014). Tekanan kerja di kalangan kakitangan awam di ibupejabat polis kontinjen Selangor, Shah Alam. Diploma Eksekutif Pengurusan (Pentadbiran dan Operasi), Pusat Pendidikan Berterusan Universiti Malaya, 2015.

Krejcie, R. V. \& Morgan, D. W. (1970) Determining Sample Size for Research Activities. Educational and Psychological Measurement, 30, 607-610.

Lahey, B. B. (2001). Psychology: An Introduction. McGraw Hill, 2001.

Lazarus, R., \& Folkman, S. (1984). Stress, appraisal, and coping. New York, NY: Springer

Lu Yong, Xiao-Min H., Huang Xiao-Liang, Xiao-Dong Zhuang, Pi Guo, Li- Fen Feng, Wei Hu, Long Chen, Huachun Zou \& Yuan-Tao Hao (2017). The Relationship Between Job Satisfaction, Work Stress, Work-Family Conflict, And Turnover Intention Among Physicians In Guangdong, China: A Cross-Sectional Study. BMJ Open 2017;7:e014894. doi:10.1136/bmjopen-2016-014894.

Masilamani, R., Bulgiba, A., Chinna, K., Darus, A., Isahak, M., Kandiben, S., \& Koh, D. (2013). Prevalence and associated factors of stress in the Malaysian police force. ScienceDirect - Preventive Medicine, 57, S57-S59.

McShane, S. L., \& Von Glinow, M. A. (2000). Organizational Behavior: Emerging realities for the workplace revolution. USA: McGraw-Hill Higher Education.

Md Safian Mohd Tahuddin (2007). Kesan Aspek Kesihatan Terhadap Produktiviti Kerja Dalam Kalangan Pensyarah Maktab Perguruan. Universiti Sains Malaysia.

Metta Astari, N., \& Sudibya, I. (2018). Pengaruh Work Family Conflict Terhadap Stres Kerja Dan Kepuasan Kerja. E-Jurnal Ekonomi Dan Bisnis Universitas Udayana, 18951926. doi:10.24843/EEB.2018.v07.i07.p05

Mohd Majid Konting. (1990). Kaedah penyelidikan pendidikan. Kuala Lumpur: Dewan Bahasa dan Pustaka.

Morgan, C. T., King, R. A., Weisz, J. R., \& Schopler, J. (1986). Introduction to psychology. New York: McGraw-Hill.

Netemeyer, R. G., Boles, J. S. \& Mcmurrian, R. (1996). Development and Validation of Work-Family Conflict and Family-Work Conflict Scales. Journal Of Applied Psychology, 81(4), 400-410.

Noor Adilah Adnan (2013). Hubungan antara stres, konflik kerja-keluarga dan perilaku merokok dalam kalangan pekerja. Universiti Malaysia Terengganu.

Nursyazlin Yatie Mohd Zaidi \& Noraini Abdol Raop (2017). Faktor-Faktor Yang Mempengaruhi Tekanan Kerja Dalam Kalangan Anggota Polis: Satu Kajian Di Kem Batalion 9 Pga Kuala Terengganu. Malaysian Journal of Social Science, 2(1), 103116.

Pallant, J. (2001). SPSS survival manual - a step by step guide to data analysis using SPSS for windows (version 10). Buckingham Open University Press.

Putra, I Gusti Ayu Yuliana Lestari., \& I Nyoman Sudharma. (2016). Pengaruh Iklim Organisasi Dan Stres Kerja Terhadap Kepuasan Kerja Karyawan Pada Hotel Asana Agung Putra Bali. E-Jurnal Manajemen Unud, 5(9), 5524-5553.

Putra, I. K. A. A. A., Syaifudin, A., \& Adinatha, N. N. M. (2014). Hubungan Gaya Kepemimpinan Kepala Ruangan Dengan Kinerja Perawat Pelaksana Di Rumah Sakit Umum Daerah Raa Soewondo Pati. Prosiding Konferensi Nasional II PPNI Jawa Tengah 2014. 
Rajak Adnan. (2013). Pengaruh Konflik Interpersonal, Work-Family Conflict Dan Stres, Terhadap Kepuasan Kerja Dan Dampaknya Terhadap Kepuasan Hidup. Jurnal Siasat Bisnis, 17(2), 131-156

Rice, P. L. (1999). Stress and Health (2nd ed.). California: Brookes/Cole.

Robbins, S. P. (2006). Perilaku Organisasi (alih bahasa Drs. Benjamin Molan), Edisi Bahasa Indonesia, Klaten: PT INT AN SEJATI

Seery, M. D., Silver, R. C., Holman, E. A., Ence, W. A., \& Chu, T. Q. (2008). Expressing thoughts and feelings following a collective trauma: Immediate responses to 9/11 predict negative outcomes in a national sample. Journal of Consulting and Clinical Psychology, 76(4), 657-667. https://doi.org/10.1037/0022-006X.76.4.657

Selye, H. (1976). The stress of life (Rev. ed.). New York, NY: Mc GrawHill.

Simunic, A., \& Gregov, L. (2012). Conflict Between Work And Family Roles And Satisfaction Among Nurses In Different Shift Systems In Croatia: A Questionnaire Survey. Archives of Industrial Hygiene and Toxicology, 63(2), 189-197.

Siti Rahayah Ariffin. (2003). Teori, konsep \& amalan dalam pengukuran dan penilaian. Bangi: Pusat Pembangunan Akademik UKM.

Thi, L. S. (1998). A case study of factors causing stress to managers and executive at work. Tesis. Universiti Malaya.

Yavas, U., Babakus, E., \& Karatepe, O. M. (2008). Attitudinal and behavioral consequences of work-family conflict and family-work conflict: Does gender matter? International Journal of Service Industry Management, 19, 1, 7-31. https://doi.org/10.1108/09564230810855699

Zaharah, H., Ahmad, A. S., Saedah, S., Mohd, R. M. J., Abdul, M. A. \& NurulRabihah, M. N. (2017). Hidup Berkeluarga Melalui Didikan Amalan Q-Rohani (Afektif) : Satu Pendekatan Fuzzy Delphi. Al-Hikmah, 9(2), 16-31. 